\title{
Material and Symbolic Economies: Letters and Gifts in Early Medieval China
}

\section{Citation}

Tian, Xiaofei. "4 Material and Symbolic Economies: Letters and Gifts in Early Medieval China." In A History of Chinese Letters and Epistolary Culture, pp. 135-186. Brill, 2015.

\section{Published Version}

doi:10.1163/9789004292123_006

\section{Permanent link}

http://nrs.harvard.edu/urn-3:HUL.InstRepos:29037391

\section{Terms of Use}

This article was downloaded from Harvard University's DASH repository, and is made available under the terms and conditions applicable to Open Access Policy Articles, as set forth at http:// nrs.harvard.edu/urn-3:HUL.InstRepos:dash.current.terms-of-use\#OAP

\section{Share Your Story}

The Harvard community has made this article openly available.

Please share how this access benefits you. Submit a story.

Accessibility 
Material and Symbolic Economies:

Letters and Gifts in Early Medieval China*

\section{Xiaofei Tian}

Harvard University

This paper examines a group of letters in early medieval China, specifically from the turn of the third century and from the early sixth century, about gift giving and receiving. Gift-giving is one of the things that stand at the center of social relationships across many cultures. "The gift imposes an identity upon the giver as well as the receiver." It is both productive of social relationships and affirms them; it establishes and clarifies social status, displays power, strengthens alliances, and creates debt and obligations. This was particularly true in the chaotic period following the collapse of the Han empire at the turn of the third century, often referred to by the reign title of the last Han emperor as the Jian'an 建安 era (196-220). At such a time of social disintegration, along with feasting, a powerful social institution that brought people together and reinforced the values of fellowship and civility, gift-giving practices constituted material and symbolic exchanges that fostered bonds, rebuilt hierarchical structures and reconstituted the community.

Modern gift theory was largely initiated by anthropologist Marcel Mauss (1872-1950) in the early twentieth century, and has subsequently become an interdisciplinary inquiry pursued by

\footnotetext{
* The draft of this paper was read at the Workshop on "Letter Writing \& Epistolary Culture in China" at University of Colorado at Boulder in August 2012 and, in part, at the Medieval Workshop at Rutgers University in May 2013. I thank the participants of the workshops and my discussant at the Medieval Workshop, Professor Meow Hui Goh, for questions and comments.

${ }^{1}$ Schwartz, "The Social Psychology," 2.
} 
scholars from fields as diverse as anthropology, sociology, economics, folklore, history, and literary theory. The greatest contribution of Mauss is to situate the apparently simple exchange of gift in a complicated network of social rules and obligations, and show that reciprocity is a key term in gift-giving that operates as a process of exchange and circulation. ${ }^{2}$ Derrida extends the idea of reciprocity and argues that, since all gifts implicate the recipient in social obligations, a true gift must not appear as a gift, or it would not be a gift at all: "For there to be gift, there must be no reciprocity, return, exchange, countergift, or debt."3 Derrida's argument about the impossibility of the gift draws attention to the gift's aggressive nature: in that it implicitly demands a return, a gift is just like an insult or a blow. Indeed, sometimes a gift itself serves as an insult: in the early third century, the minister of the Shu-Han kingdom, Zhuge Liang 諸葛亮 (181-234), once sent the gift of female clothes to his nemesis Sima Yi 司馬懿 (179-251), the Wei commander, in a desperate effort to challenge Sima Yi to military action; Sima Yi's refusal to fight proved the best return gift because it matched Zhuge Liang's present in its ill intention. ${ }^{4}$ To study gift-giving is therefore to study the process of exchange and circulation in which an object takes on additional value, economic or symbolic or both, besides its use value.

The exchange of letters in many ways evokes the exchange of gifts. To address a letter to someone implicitly carries with it a request for timely response and reciprocation, and the

\footnotetext{
${ }^{2}$ Mauss's most famous work is Essai sur le Don, Forme et Raison de l'Échange dans les Sociétés archaïques, translated by Ian Cunnison into English as The Gift: Forms and Functions of Exchange in Archaic Societies. 
epistolary conventions create a complex system of rules and constraints that both define and maintain social relations. Furthermore, a letter itself is also a material object. As Antje Richter states in her ground-breaking study of epistolary culture in early medieval China, "The materiality of letters is more pronounced than that of many other genres." This fact is particularly important in the case of a famous calligrapher whose handwriting is prized for its aesthetic and commercial value. ${ }^{6}$ In a well-known story, the statesman Xie An 謝安 (320-85) deliberately wrote his reply in the blank end space of a letter from Wang Xianzhi 王獻之 (34486), a celebrated calligrapher, and sent it back to Wang to show that he did not care to preserve Wang's calligraphy, to Wang's chagrin. ${ }^{7}$ This story underlines the physical nature of a letter and highlights the resemblance of the presentation of a letter to that of a gift. Thus, exchanging letters regarding giving and receiving a gift constitutes yet another layer of object transference, one that delimits and accentuates the symbolic significance of gift exchange.

In the letters discussed in this paper, the transaction between letter writer and letter recipient happens on both material level and discursive level. The letters constitute a verbal and material economy that is closely tied to the production of value of the circulated objects, and enable a new balance to be established between donor and recipient. The presence of the letters gives nuances to and even defines the gifts, and infinitely complicates the concept of reciprocity in gift exchange as initially proposed by Marcel Mauss.

\footnotetext{
${ }^{5}$ Richter, Letters and Epistolary Culture, p. 17.

${ }^{6}$ For a description of the emergence and subsequent prevalence of this phenomenon in early medieval China, see the section on "Calligraphy and Letter Writing” in Richter, Letters and Epistolary Culture, pp. 23-26.

${ }^{7}$ The anecdote can be found, among other early sources, Zhang Huaiguan's 張懷瓘 (fl. early eighth century) Shu duan 書斷, which was completed in 724. Lidai shufa lunwen xuan, 205.
} 
1. The Gift of Death and Life

Like any social action, the general significance of gift giving must be instantiated in specific contexts. The symbolic nuances of a gift vary in different situations, and letters accompanying gifts are often essential for the correct interpretation of the gifts. In this section I focus on a pair of letters exchanged between Cao Cao 曹操 (155-220), the powerful warlord, and Yang Biao 楊 虎 (142-225), an eminent senior minister, as well as on a pair of letters exchanged between Cao Cao's wife, Lady Bian 六 (159-230), and Yang Biao's wife, Lady Yuan 袁. ${ }^{8}$ As we will see, the letters of the gift givers are not only crucial for the receivers to decipher the meaning of the gifts but also constitute a gift in themselves that requires proper encoding.

Yang Biao was from an old elite family that had occupied prestigious official positions in the Han court for generations. Seeing that Cao Cao had become the sole power-holder at the court and the days of the Han dynasty were numbered, Yang Biao had retired under the pretext of frail health in 206. His son Yang Xiu 楊修 (d. 219), however, served on Cao Cao’s staff. Because of his impressive family background and outstanding talent, Yang Xiu was eagerly sought after by Cao Cao’s sons, Cao Pi 曹丕 (187-226) and Cao Zhi 曹植 (192-232), who competed fiercely with each other to be Cao Cao's chosen heir and tried to gain personal

\footnotetext{
${ }^{8}$ The letters are preserved in juan 10 of Gu wen yuan 古文苑, a Tang/Song anthology of pre-Tang literature. For a recent study of the making of Gu wen yuan, see Wang Xiaojuan, Gu wen yuan lungao. Fragments of Cao Cao's letter are also seen in Sui, Tang, and Song encyclopedias such as Beitang shuchao 北堂書鈔, Chuxue ji 初學記 and Taiping yulan 太平御覽. The letters are preserved in an abbreviated form in Yin Yun’s 殷去 (471-529) Xiaoshuo 小 說, an anecdotal collection that is lost and has been reconstituted from various works. Yin Yun xiaoshuo, 91-93.
} 
influence by winning allegiance from worthy men. In 217, Cao Cao, already enfeoffed as King of Wei by the Han emperor, designated Cao Pi as the Crown Prince. Two years later, concerned that Yang Xiu's intelligence and his friendship with Cao Zhi might cause political instability, Cao Cao had Yang Xiu executed. ${ }^{9}$ After Yang Xiu's execution, Cao Cao sent a number of lavish gifts to Yang Biao and his wife along with the following letter. ${ }^{10}$

操白 Cao lets you know:

與足下同海內大義 I share with you, sir, the great principle within the four seas.

足下不遺 You, sir, did not abandon me,

以賢子見輔 and sent your worthy son to assist me.

比中國雖靖青等, ately, although the Central Plains have been appeased,

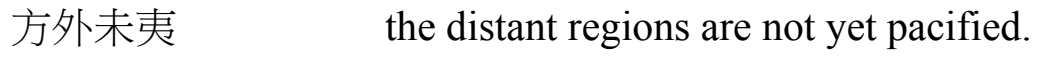

今軍征事大 The current military affairs are grave matters,

百姓騷擾 and the common folk are not at ease.

吾制鐘鼓之音 I set the tone of bells and drums,

主簿宜守 which my administrators should observe.

而足下賢子恃豪父之勢 And yet, relying on the influence of his powerful father,

每不與吾同懷ｙour worthy son frequently went against my wishes.

即欲直繩 I had wanted to regulate him with law,

\footnotetext{
${ }^{9}$ Sanguo zhi 19.558-560.

${ }^{10}$ Gu wen yuan 10.81. Quan Sanguo wen 3.1070. For modern annotations, see Cao Cao ji yizhu, 184-85; Cao Cao ji $z h u, 174-76$.
} 


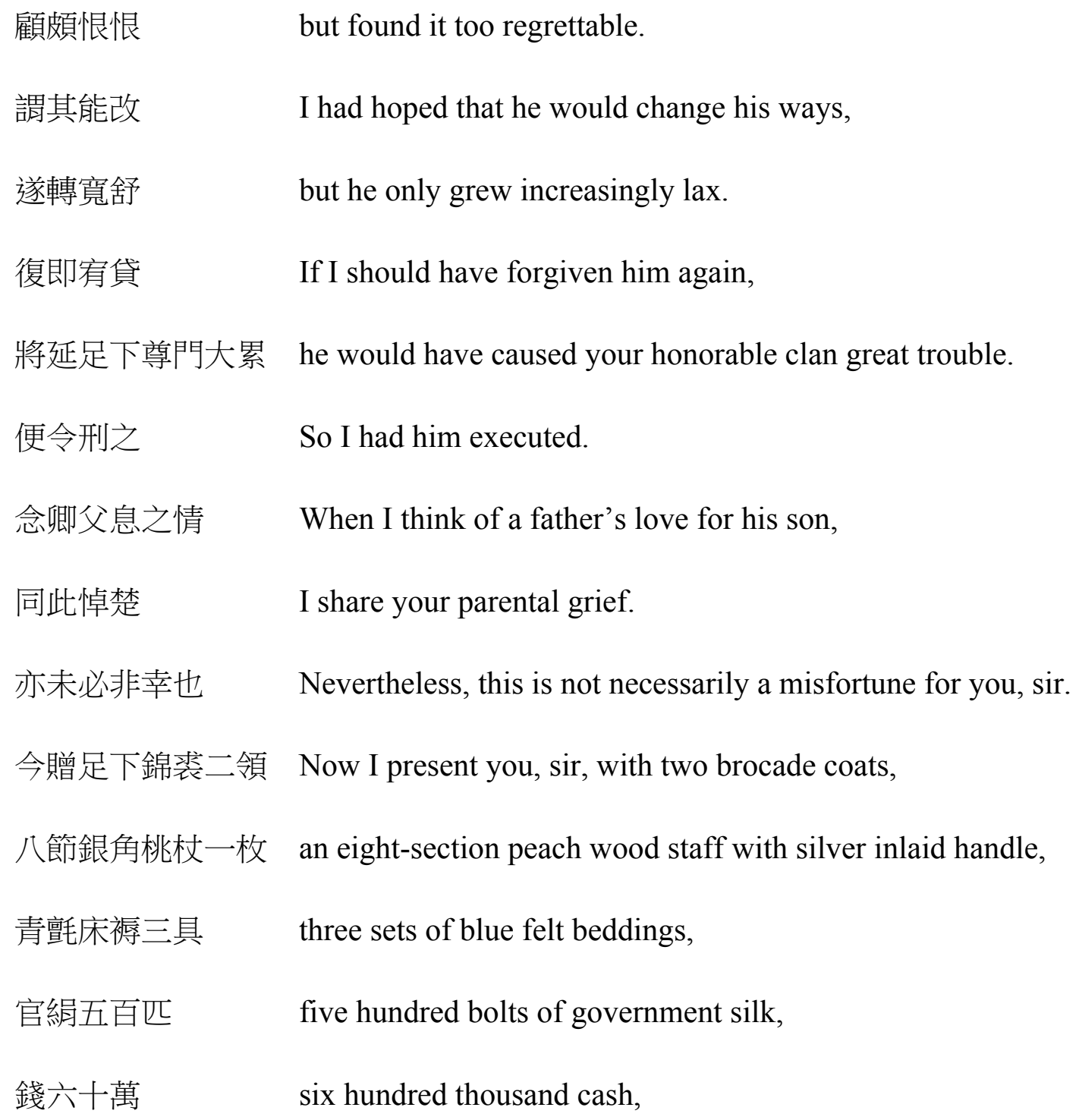


並遺足下貴室 I also present your esteemed wife

錯綵羅縠震一領ｏne multi-colored thin gauze robe,

織成靴一量 one pair of brocatelle boots,

有心青衣二人 and two thoughtful maids

長奉左右 who will remain in her service.

所奉雖薄 Although my gifts are insignificant,

以表吾意等等ey are meant to convey my sentiments.

足下便當慨然承納 I ask you, sir, to accept them generously

不致往返 and save the messenger from going back and forth.

If the rich gifts described in the letter had been sent without this letter, they most likely would have been construed as a gesture of consolation and placation, an expression of feelings of guilt on Cao Cao's part and his attempt to compensate for the taking of Yang Xiu's life; but the presence of the letter greatly complicates the picture.

The letter opens with the assertion that he, Cao Cao, shares with Yang Biao "the great principle within the four seas." What the "great principle" might be is anyone's guess - the modern annotators take it to refer to Cao Cao and Yang Biao's common vassalage to the house of the Han, ${ }^{11}$ and it might very well be the case, as Cao Cao kept up the appearance of being a subject to the Han emperor all his life. Rhetorically, the assertion places Yang and Cao on the same side, which is also the righteous side. This makes it difficult for Yang to oppose Cao on ideological grounds. It is perhaps not a coincidence that the word "share" (tong) appears three

${ }^{11}$ Cao Cao ji yizhu, 185. 
times in the letter: the first time is in this assertion, and the third time is when Cao claims he shares Yang Biao's grief as a father. These gestures of accord, sympathy, and pacification are, however, undercut by the ominous threat, not so thinly veiled, in the main body of the letter. Just as the second time Cao uses the word "share" is to denounce Yang Xiu for going against his wishes ( $b u$ yu wu tong huai, literally "not sharing my concerns"), he intimates that any failure to "share" Cao Cao's concerns leads to dire consequences.

In the letter, Cao Cao describes the contemporary political situation as a precarious one. Under such circumstances, it is all the more important for his staff to strictly follow the orders of their leader, and any recalcitrance is understood not only as personally disrespectful to Cao Cao himself but also as implicitly endangering to the state. "And yet, relying on the influence of his powerful father, Your Lordship's worthy son frequently went against my wishes." To attribute Yang Xiu's delinquency to a misplaced family pride and his reliance on an influential father is an important rhetorical move, for it directly connects Yang Xiu's transgressions with Yang Biao himself, and the inherent menace of such a claim is unmistakable.

After stressing his forgiveness of Yang Xiu's past offenses, Cao Cao declares: "If I should have forgiven him again, he would have caused Your Lordship's honorable clan great trouble. So I had him executed." Cao Cao turns everything around by showing Yang Biao how he has done him an enormous favor by executing his son. In order to drive the lesson home, Cao Cao reiterates it in no ambiguous terms: "this," he says, "is not necessarily a misfortune for Your Lordship." What follows is a list of lavish gifts for Yang Biao and his wife. It is worth noting that the gift of six hundred thousand cash is discreetly inserted in the middle of the inventory of clothes, carriage, horse, servants, and so on and so forth; as a result, even the monetary gift takes on the aura of an "object" for use in daily life like other things and loses some of its crassness. 
Nevertheless, the gift list raises the question of value: how much, after all, could be considered an adequate compensation paid to the parents for the taking of their son's life? The answer is, obviously, nothing — or at least nothing of economic value. But Cao Cao's letter makes it clear that the real gift he bestows on Yang Biao is the gift of life: by executing Yang Biao's wayward son, Cao Cao has saved Yang Biao himself and his entire clan. ${ }^{12}$

In this case, it is evidently not possible, nor desirable, for Yang Biao to reciprocate Cao Cao's gifts in any material form. The principle of reciprocity nevertheless holds true. In some ways, Cao Cao's material gifts — money, clothes, horse, carriage, and other things — are return gifts for Yang Biao’s initial, equally physical gift of his “worthy son," who, as Cao suggests at the beginning of the letter, was sent to Cao by Yang Biao himself. The material objects transferred from Cao Cao to Yang Biao are payment given as reparation for services and loss of life. But Cao's letter constitutes a gift in a more immaterial form, which places Yang Biao under the obligation to acknowledge and give back something similar in nature to complete the giftgiving sequence. Yang Biao's reply letter, as we will see, proves to be an adequate return gift.

The two letters are placed side by side below to demonstrate the perfect symmetry between Cao Cao's letter and Yang Biao's reply. ${ }^{13}$

Cao lets you know: I share with you, sir, the 彪白。雅顧隆篤, 每蒙接納, 私自光慰。 great principle within the four seas.

\footnotetext{
${ }^{12}$ The extermination of an offender's whole clan was not an uncommon punishment, and indeed Cao Cao himself was known to mete out such punishment to his enemies, a fact that must have added weight to his words of intimidation. See Sanguo zhi 1.44, 1.53.

${ }^{13}$ Gu wen yuan 10.81. Quan hou Han wen 51.756.
} 
Biao lets you know. You favor me deeply and sincerely. As I frequently have the honor of being received by you, I feel flattered and comforted in my heart.

You, sir, did not abandon me, and sent your worthy son to assist me.

Lately, although the Central Plains have been appeased, the distant regions are not yet pacified. The current military affairs are grave matters, and the common folk are not at ease. I set the tone of bells and drums, which I expect my administrators to observe. And yet, relying on the influence of his powerful father, your worthy son frequently went against my wishes.
小兒頑图，謬見采錄，不能期效，以報所

愛。

My humble son was disobedient and dimwitted; he had been selected and appointed by mistake. I could not expect him to accomplish anything to repay those who loved him.

方今軍征未㗇, 其備位匡政, 當與翏力一 心，而寬玩自稽，將違法制。

The current military affairs are extremely busy. As he was made to fill in a position and assist your governance, he should have been of one mind with you. Instead, he was lax and careless in regulating himself, and violated laws and rules. 


\section{相子之行，莫若其父，恆慮小兒必致傾敗。}

I had wanted to regulate him with law, but

found it too regrettable. I was hoping that he would change his ways while he only grew increasingly lax. Should I have forgiven him again, he would have caused your honorable clan great trouble. So I had him executed.

When I think of a father's love for his son, I share your parental grief. Nevertheless, this is not necessarily a misfortune for you, sir.

Now I present you, sir, with two brocade coats, an eight-section peach wood staff with silver inlaid handle, three sets of blue felt beddings, five hundred bolts of government silk, six hundred thousand cash, a four-windowed, curtained carriage made of seven aromatic
足下恩恕, 延罪迄今。

In observing and evaluating a son's behavior, no one is better than his father. I had always worried that my son would one day meet with downfall. You, sir, had graciously tolerated him and postponed his punishment until now.

近聞問之日, 心腸酷裂, 凡人情誰能不爾。 深惟其失，用以自釋。

On the day when I heard the news, my heart was rent in pieces. This, I am afraid, is human nature; who would not feel the same? All I can do is to reflect deeply on his wrongdoing and by this means console myself.

\section{所惠馬及雜物, 自非親舊, 孰能至斯。}

As for the horse and other miscellaneous things you presented me with, only relatives and old friends would do so much. 
woods and with painted wheels, two black

cows, one fine eight-hundred-league steed, ten

sets of copper-decorated saddle and reins made

of crimson flannel, one tapestry with hanging

bells, and two servants. I also present your

esteemed wife one multi-colored thin gauze

robe, one pair of zhicheng brocade boots, and

two thoughtful maids who will remain in her

service.

Although my gifts are insignificant, they are＼cjkstart省覽眾賜, 益以悲懼。

meant to convey my sentiments. I ask you, sir, As I examine the various gifts you have

to accept them generously and save the bestowed on me, they only increase my sorrow

messenger from going back and forth. and apprehension.

In his reply, Yang not only responds to Cao point by point, but also elaborates on each statement made in Cao's letter while following strictly, to borrow Cao's musical metaphor, the “tone" set by Cao. To Cao's reconciliatory remark about sharing the "great principle within the four seas," he responds by expressing gratitude for Cao's favor and reception. To Cao's reference to Yang Xiu as his "worthy son," he responds by describing Yang Xiu as "disobedient and dim-witted." He echoes verbally Cao's description of the contemporary political situation, and basically declares that Yang Xiu deserved his punishment. While Cao criticizes Yang Xiu for failing to share his concerns (tong huai), he agrees that Yang Xiu should indeed have been 
"of one mind" (yi xin) with Cao. He recognizes Cao's "gracious tolerance” of Yang Xiu's faults, and admits to feeling pain over his execution. His apologetic remark, "This, I am afraid, is human nature; who would not feel the same?” reverberates Cao's comment on "a father's love for his son," but this remark is immediately followed by his admission of Yang Xiu's wrongdoing, an act of reason to counteract the natural overflow of fatherly grief.

As opposed to the detailed itemizing and description of the gifts in Cao's letter, however, Yang Biao reduces the long list to a brief mention of "the horse and other miscellaneous things," an understatement becoming his status as a senior minister from an old noble family. And yet, he shows his acute awareness of the symbolic value of the objects and his understanding of Cao Cao's "sentiments," of which the objects are a mere sign, by saying that the gifts "only increase my sorrow and apprehension." In short, Yang Biao’s reply gives Cao Cao exactly what he wants and expects: an acknowledgement of the power imbalance between them and of total submission.

Cao Cao's gifts to Yang Biao, like the gifts given out by Merovingian and Carolingian kings and nobles, are meant to placate and subdue, and must be treated "as a category of power and as a political strategy." 14 Without his accompanying letter, however, the gifts might simply be regarded as compensation for a life taken and/or an expression of guilt. Cao Cao's letter makes it clear that guilt is certainly not a part of the "sentiments" which he wishes to convey. Instead, he demonstrates to Yang Biao both his good will by giving lavish material gifts and the potentially dire consequences of rejecting his good will by bestowing the most costly gift of all: the gift of life. To refuse the material things would thus mean rejecting the gift of life that comes along with them. Yang Biao understands this well and duly fulfills the obligations Cao Cao's

\footnotetext{
${ }^{14}$ Curta, "Merovingian and Carolingian Gift Giving," 677.
} 
giving creates in him: he accepts the gifts, and writes a reply letter affirming his submission as a gesture of reciprocation.

It is intriguing to observe another pair of letters exchanged between Cao Cao's wife, Lady Bian, and Yang Biao's wife, Lady Yuan, under the same circumstances. The central question to be considered here is why it is apparently acceptable for Lady Yuan to reject Lady Bian's gifts. Once again, the letters play a vital role in bringing out the meaning of the sending and refusing of the gifts.

Lady Bian's letter is as follows: ${ }^{15}$

市頓首 Bian knocks her head on the ground.

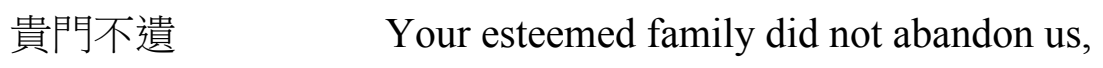

賢郎輔佐Ａnd your worthy son assisted the governance of the state.

每感篤念 I was always moved by such profound concerns

情在凝至 And felt immensely grateful.

賢郎盛德熙妙Ｙour worthy son possessed bright and marvelous virtue,

有蓋世文才 And was endowed with a literary talent matchless in the world.

闔門欽敬 My entire family admired and respected him,

寶用無已 And treasured his service endlessly.

方今騷擾 The political situation today is turbulent,

戎馬屢動 And the army is frequently deployed.

主簿股肱近臣 The Recorder was like his lord's arms and legs, ${ }^{16}$

${ }^{15}$ Gu wen yuan 10.82. Quan Sanguo wen 12.1120. 
征伐之計

事須敬次

官立金鼓之節

而聞命違制

明公性急忿然

在外輙行軍法

市姓當時亦所不知

聞之心肝塗地

驚愕斷絕

悼痛酷楚

情自不勝

夫人多容

即見垂恕

故送衣服一籠

文絹百匹

房子官錦百斤

私所乘香車一乘

牛一頭
And in planning for military campaigns,

He should respectfully consult his superior.

The gong and drum beat has been publically established,

And yet he disobeyed an explicit order.

His Lordship, who has a short temper, was provoked to anger,

And applied military punishment immediately in the army outside.

I did not know anything about it when it happened;

Then, upon hearing the news, my heart was broken.

Shocked and grieved to no end,

I felt such an incredible sadness

That it was unbearable.

You, madam, have a large heart,

And deign to forgive me.

Thereupon I present you with a case of clothes,

A hundred bolts of patterned silk,

A hundred catties of government brocade from Fangzi, ${ }^{17}$

My personal carriage made of aromatic wood,

As well as an ox.

\footnotetext{
${ }^{16}$ Yang Xiu was serving as Recorder on Cao Cao's staff at the time of his execution.

17 “Brocade” (jin 錦) should be emended to “cotton” (mian 綿). Fangzi (in modern Hebei) was famous for its highquality cotton in the Han.
} 
誠知微細 I certainly know these gifts are very humble,

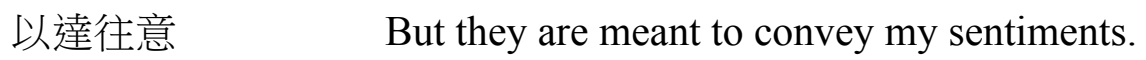

望為承納 I hope you, madam, will agree to accept them.

Lady Yuan's reply letter reads: ${ }^{18}$

彪袁氏頓首頓首 Biao's wife, Yuan, knocks her heard on the ground repeatedly.

路跂雖近 Although the distance between us is short,

不展淹久 I have not visited you for a long time.

歎想之勞 I suffer from longing for you,

情抱山積 ～My pent-up feelings piling like mountains.

曹公匡濟天下 Lord Cao has rectified and saved the world;

遐邇以寜 Places near and far all rely on him for peace.

四海歸仰 People within the four seas turn to him for protection,

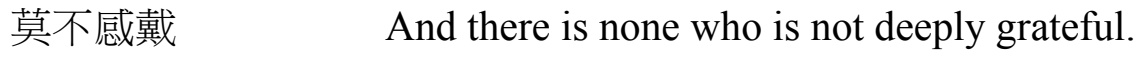

小兒疏細 My humble son was careless and shallow;

謬蒙采拾等 had been chosen for office by mistake.

未有上報 Indeed he was unable to repay the favor

果自招罪戾 And only got himself in trouble.

念之痛楚 When I think of this, I am so pained

${ }^{18}$ Gu wenyuan 10.82. Quan hou Han wen 96.991. 
五內傷裂 That my inner organs are wounded and torn.

尊意不遺 Your do not abandon me,

伏辱惠告 And stoop to write me about it.

見明公與太尉書 I have already seen His Lordship's letter to the Grand Marshall, ${ }^{19}$

具知委曲 So I am well acquainted with the details.

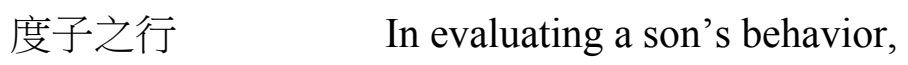

不過父母 None is better than his father and mother.

小兒違越烈 My humble son transgressed by disobeying orders

分應至此 And received the punishment he deserved.

憐其始立之年 I only pity him for having ended his life

畢命埃土 $\quad$ When he was just turning thirty years old, ${ }^{20}$

遺育孤幼 And for having left behind a fatherless young child.

言之崩潰 ～Even as I speak of it, I am breaking down.

明公所賜已多 His Lordship has already bestowed many gifts on us,

又加重賚禮 To which you now add so much more.

頗非宜荷受 It is not appropriate for me to accept them.

輙付往信 I have asked the messenger to take them back. ${ }^{21}$

\footnotetext{
${ }^{19}$ Yang Biao was Grand Marshall, one of the "Three Dukes," a prestigious title with little actual power.

${ }^{20}$ According to Sima Biao’s 司馬彪 (243-306) Xu Han shu 續漢書, cited in the Hou Han shu commentary, Yang Xiu was forty-four years old (forty-five by Chinese reckoning) when he died. Hou Han shu 54.1789.
} 
Compared with her husband's letter to Yang Biao, Lady Bian's letter is much more reconciliatory in tone, praising Yang Xiu's abilities and expressing sadness for his death. While she does defend the justice of Cao's decision and her phrasing of the current military situation echoes Cao's own, she is also apologetic about his "short temper," hinting that if she had known in time, she might have tried to do something to help. The gifts she offers, consisting of clothes, textiles, and most notably her own carriage, are less extravagant compared with Cao's gifts but more "feminine" and personal.

Lady Yuan's reply largely constitutes a mirror image of Lady Bian’s letter. If Lady Bian praises Yang Xiu and conveys regrets about Cao Cao's temper, then she unsurprisingly eulogizes Cao Cao's accomplishments and affirms that Yang Xiu did deserve his punishment. In contrast with the more restrained epistles of Cao Cao and Yang Biao, her letter lays stress on the emotional aspect of the incident, lamenting Yang Xiu's premature death and his orphaned son; and yet, the intensely emotive tone is in sync with Lady Bian's open expression of feelings. However, by refusing the gifts, Lady Yuan rejects Lady Bian's attempt to create a social bond between the two of them. It is interesting to see how Lady Bian delineates a space for herself as an independent person, however delusional it might be, by distancing herself from her husband ("he has such a temper"; "I had no idea that he did that"; and "yes he sent gifts, but these gifts are mine"). Lady Yuan, on the other hand, defines herself entirely as Yang Biao's wife and Yang Xiu's mother: she refers to herself as "Biao's wife, Yuan," instead of simply "Yuan;" she reveals that Yang Biao has shared Cao Cao's letter with her; she states that "no one knows [Yang Xiu]

\footnotetext{
${ }^{21}$ In punctuating the last four lines of the letter, I have followed Zhou Lengjia rather than Yan Kejun. See Yin Yun Xiaoshuo, 92-93.
} 
better than his own father and mother," By doing so, she manages to escape from being drawn into a friendship "between the girls." Again, power is at the roots of the issue.

In describing gift giving practice in medieval Iceland, William Ian Miller observes that gift giving "gave rise to social relations and adjusted the status of the parties in relation to each other. The giver gained prestige and power from the exchange. He exacted deference from the receiver and obliged him to reciprocate. ${ }^{, 22}$ By turning down Lady Bian's gifts and emphasizing the prematurity of her son's death, Lady Yuan denies Lady Bian the satisfaction of mollifying her guilty conscience, refuses to put herself in personal debt to Lady Bian and to be dominated, and insists on the irredeemable nature of her loss. Ultimately, of course, all this is acceptable only because they happen in the women's quarters, the more private and personal world "inside," in contrast with the "outside" mentioned in Lady Bian's letter and represented by Yang Biao's interaction with Cao Cao.

One final point to be made by Lady Yuan's letter is a philological one embroiled with ideological implications. The last four lines of her letter could be easily punctuated as follows:

明公所賜已多 His Lordship has already bestowed many gifts on us,

又加重賚 To which you now add so much more.

禮頗非宜 It is not quite right in terms of propriety.

荷受輙付往信 Upon receipt, I have asked the messenger to take them back.

\footnotetext{
${ }^{22}$ Miller, "Gift, Sale, Payment, Raid,” 23.
} 
That is, instead of reading $l i$ 禮 as "gift" at the end of the second line, we could read $l i$ as "[according to or in terms of] ritual propriety" at the beginning of the third line; and instead of reading he shou 荷受 (to accept) at the end of the third line, we could read it as “[upon] receipt" at the beginning of the fourth line. If we adopt this reading, the tone of the letter is much more austere, even on the edge of being disrespectful, as Lady Yuan alludes to the ritual improperness of Lady Bian's gift giving (in contrast, the other reading stresses the impropriety of the acceptance of the gifts). Since classical Chinese texts have no punctuation marks, it is up to the reader to punctuate a text according to her interpretation. The ambiguity of Lady Yuan's phrasing further complicates the power struggle implicit in gift giving, and demonstrates the crucial role played by letters in the signification of the gifts.

\section{Give and Take: Cao Pi’s Gift Politics}

During the waning years of the Han dynasty, in a world torn apart by war, famine and plague, the foremost task facing a political leader is to rebuild the community and gathering people around himself. Cao Cao and his sons were intent on collecting resources, both material and symbolic, in the form of people and objects. In the previous section we discuss Cao Cao and Lady Bian's giftgiving; in this section we will examine another set of letter and object transactions initiated by their son, $\mathrm{Cao} \mathrm{Pi}$, beginning with an instance in which Cao Pi is the receiver of a gift. According to Wei lue 魏略, Cao Pi learned that Zhong Yao 鍾揫 (151-230) had a valuable jade in his possession and coveted it; when Zhong heard of it, he gave the jade to Cao Pi, 
who subsequently wrote a letter to thank Zhong for his generosity. ${ }^{23}$ The letter, usually dated to 215 , turns out to be a fascinating demonstration and performance of political power. Both father and son were masters of making use of words as political strategies, but unlike Cao Cao, who spoke with the assurance of someone in charge when writing to Yang Biao, Cao Pi had to contend with the uncertainty of his own status at the time of writing to Zhong Yao. With his characteristic reflectiveness and delicateness, Cao Pi produces a verbally and psychologically intricate document. Effectively incorporating the classical and literary tradition, he crafts a voice that is both artful and human in its all too palpable desires and its aspiration to authority.

\section{丕白 Pi lets you know:}

良玉比德君子Ａ fine jade is compared to the virtue of a noble man;

珪璋見美詩人 Precious jade ritual vessels are eulogized by the Shi poet.

晉之垂棘 The jade from Chuiji of Jin,

魯之璵璠 The yufan jade of Lu,

宋之結綠 The Congealed Green of Song,

楚之和璞 And He’s Jade of Chu: ${ }^{24}$

\footnotetext{
${ }^{23}$ Wei lue, a history of Wei written by Yu Huan 魚䅈 (fl. the third century), is no longer extant. This incident and the letter are cited in Pei Songzhi's Sanguo zhi commentary. See Sanguo zhi 13.396. The letter is also included in Wen xuan 文選, compiled by Xiao Tong 蕭統 (501-531), with some variants. Wen xuan 42.1899-1900. Also see Quan sanguo wen 7.1088. See David R. Knechtges' essay, "Letters in the Wen xuan,” in this volume.

24 "He's Jade" refers to the jade named after its discoverer, Bian He from Chu. Bian He found an uncut jade and presented it to the king of $\mathrm{Chu}$, who had his jade craftsman look at it; the craftsman declared it to be a worthless piece of rock, and the king subsequently had Bian He's foot cut off as a punishment for lying to the king. When the
} 
價越萬金等 Their prices exceed ten thousand gold pieces;

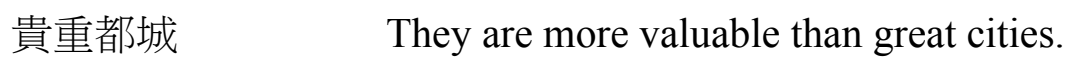

有稱疇昔 They were commended in the past,

流聲將來 And their reputation extends into the future.

是以垂棘出晉 Therefore when the Chuiji jade left Jin,

虞虢雙禽 The domains of Yu and Guo both felli, ${ }^{25}$

和璧入秦 When He’s Jade entered Qin,

相如抗節 Xiangru remained steadfast to principle. ${ }^{26}$

Opening with allusions to the Classics, the letter immediately brings out the symbolic meaning of the material object being transferred, and draws the reader's attention to the political consequences of the misplacement of a gift of jade. The Wen xuan commentator Li Shan 李善 (630-689) identifies the first line of the letter as a reference to $L i j i$ 禮記: “Confucius said, 'A

king died, Bian He presented the jade to his successor; the same happened, and Bian He lost his other foot. When the third Chu king was enthroned, Bian He held the jade and wept for days and nights until the king sent someone to cut open the stone and find a priceless jade inside. This jade later was owned by the King of Zhao (see Note \#24).

${ }^{25}$ The domain of Jin was undertaking a military campaign against the domain of Guo, and offered its Chuiji jade to the domain of $\mathrm{Yu}$ as an exchange for giving the Jin army access to Guo. The ruler of Yu agreed against his minister's advice; after conquering Guo, the Jin army on its way back took Yu as well. Chunqiu Zuo zhuan 12.199, Duke $\mathrm{Xi}, 2^{\text {nd }}$ year.

${ }^{26}$ The King of Qin coveted the famous "He's jade" of Zhao and offered to exchange fifteen cities for it. the Zhao minister Lin Xiangru took the jade to Qin, but knowing the King of Qin was being insincere in his offer of exchange, he secretly sent someone to smuggle the jade out of Qin and back to Zhao. Shi ji 81.2439-2441. 
noble man's virtue is compared to jade, ${ }^{, 27}$ and the second as a reference to a Shi jing 詩經 couplet: "Gentle and dignified, / like jade ritual vessels. ${ }^{, 28}$ While a commentator like Li Shan often only singles out the one line or couplet that bears directly on the text being annotated, the entire text surrounding that one line or couplet would have resonated with a well-educated reader from the third century. The Shi jing poem from which the couplet is taken, “Juan E” 卷阿, is taken by the Mao school of Shi jing commentary to be Duke Shao's advice to the young King Cheng of Zhou to seek worthy men and employ them. ${ }^{29}$ While such exact contextualization is doubtful, in this case the poem itself does allude to the "many admirable officers" of the king, and so justifies a political reading of the poem. Zheng Xuan 鄭玄 (127-200), an older contemporary of Cao Pi and one of the most influential early commentators on Shi jing, takes “gentle and dignified" (yongyong angang 颙顒卭卭) as the qualities of a ruler; indeed, the Han dictionary Erya glosses yongyong angang as descriptive of "the virtue of a king."30

The intimate relation of a precious jade to the ruler, not to his advisors no matter how admirable they are, is not an insignificant issue. Its importance is borne out by the story associated with the second of the four famous jades of the past listed in Cao Pi's letter, namely the yufan jade of Lu. According to Zuo zhuan, the yufan jade was customarily carried by the rulers of Lu, but the powerful minister Ji Pingzi 季平子 (d. 505 BCE) wore the jade when he was acting as regent; after Ji Pingzi died, his retainer Yang Hu 陽虎 wanted to bury the jade with him, but was opposed by Zhongliang Huai 仲梁懷. Zhongliang Huai's rationale was simple: the yufan

\footnotetext{
${ }^{27}$ Wen xuan 42.1899. Li ji 48.1031.

${ }^{28}$ Mao shi 17.628 .

${ }^{29}$ Mao shi 17.626.

${ }^{30} \operatorname{Er} y a 3.57$.
} 
jade belonged to the ruler; now that a new ruler was established, the jade should go to the new ruler instead of following Ji Pingzi, a minister, underground. ${ }^{31}$

A highly symbolic ritual object like jade must be kept in the right hands; otherwise the consequences could be disastrous, as illustrated by the example of the domain of Yu that was destroyed because it became greedy for the Chuiji jade, the state treasure of the domain of Jin; or, in the case of the ambitious Qin that tried to seize the illustrious "He's jade," the king of Qin set out to swindle but only wound up being swindled. The physical properties of a precious jade resemble the virtue of a "noble man," who exerts rightful ownership over the jade because of this material/spiritual affinity. The "noble man” (junzi 君子) is literally “the son of a lord," the archaic meaning of the term junzi. Cao Pi was certainly worthy of such an appelation by virtue of his birth and his father's status.

The very enumaration of the four famous jades of the past in Cao Pi's letter subtly conveys to Zhong Yao the message about rightful ownership, as the verbal structure echoes another letter in history—the one written by Fan Sui 范睢 to King Zhao of Qin (r. 306-251 B.C.E.). Fan Sui, still a humble commoner at the time, is trying to persuade the king to give him an audience. He compares worthy men (such as himself) to precious jades that have once been overlooked by good craftsmen before being recognized for what they truly are:

且臣聞周有砥砨, 宋有結綠, 梁有縣藜, 楚有和朴, 此四寶者, 土之所生, 良工之所失也, 而為天下名器。然則聖王之所弃者, 獨不足以厚國家乎?

Besides, I have heard that Zhou has Di'e, Song has Congealed Green, Liang has Xuanli, and Chu has He's Jade. These four treasures came from the earth and

\footnotetext{
${ }^{31}$ Chunqiu Zuo zhuan 55.958, Duke Ding, $5^{\text {th }}$ year.
} 
were all misrecognized by fine craftsmen; but in the end they turned out to be famed objects of the world. This being the case, might not those abandoned by sage kings bring profit to a state? ${ }^{32}$

Presumably, however, what really moved King Zhao is the remark immediately following the above passage, which makes a jab at the noble lords holding too much power at the expense of the king's interest. This remark, slyly inserted in the middle of Fan Sui's letter, would certainly strike a chord with King Zhao, who was contending with his powerful uncle and brothers for control over the state.

臣聞善厚家者取之於國, 善厚國者取之於諸侯。天下有明主則諸侯不得擅厚 者, 何也? 為其割榮也。

I have heard that those who are good at profiting one's household takes from the state, and that those who are good at profiting the state take from the noble lords. When a wise ruler presides over the world, then the noble lords are unable to monopolize profit. Why is this? It is because they would have taken from the ruler's glory.

Both worthy men and precious jades — a figure of the worthy men — must become the possession of the ruler; only an unwise ruler would allow his courtiers to take for themselves what should belong to the ruler alone. This much is made clear by Fan Sui's letter to the King of Qin —and

\footnotetext{
${ }^{32}$ Shi ji 79.2405 .
} 
through borrowing, echoing, and extending the classical and literary tradition, by the opening passage of Cao Pi's letter to Zhong Yao.

Then Cao Pi turns to speak of his own lack, and the desire borne out of the lack, in implicit contrast with Zhong Yao's possession of the jade:

㟳見玉書稱美玉 I have seen beautiful jade described in a book on jade: ${ }^{33}$

白如截肪

黑譬純漆

赤擬雞冠

黃侔蒸栗

側聞斯語

未睹厥狀
"The white ones are like sliced fat;

The black ones are like pure lacquer;

The red ones may be compared to the crest of a rooster;

The yellow ones equal the color of steamed chestnut."

Though I have heard of such,

I have never actually witnessed it.

It is interesting to observe how desire is fanned by reading, with the textual "seeing" and the real-life "witnessing” paired off in contrast. Textual knowledge laid out in sensuous detail precedes actual knowledge, and acts as a powerful inducement to seek out the latter.

\footnotetext{
${ }^{33}$ I suspect “a book on jade” ( $y u$ shu 玉書) should read “Wang's book” 王書 (Wang shu), the characters for $y u$ and wang resembling each other closely. “Wang's book” would be a reference to the first century scholar Wang Yi’s 王 逸 work entitled Zhengbu lun 正部論, which was lost in the sixth century. See Sui shu 34.998. A fragment quoted in the early Tang encyclopedia Yiwen leiju 藝文類聚 reads: “Someone asks me about the standard for jade. I reply, 'The red ones are like the crest of a rooster; the yellow ones are like steamed chestnut; the white ones are like pork fat; the black ones are like pure lacquer. This is the standard for jade” 或問玉符, 曰: 赤如雞冠, 黃如蒸栗, 白如豬 肪, 黑如純漆, 玉之符也. Yiwen leiju 83.1428.
} 
雖德非君子 Although my merit is not that of a noble man,

義無詩人 And I lack the qualities of a shi poet,

高山景行 A high mountain and a great thoroughfare

私所仰慕 Are what I have always admired and looked up to.

然四寶邀焉已遠 However, those four treasures are already distant,

秦漢未聞有良比也 And I have never heard of a good match for them in Qin and Han.

求之曠年 I had been seeking it for many years,

不遇厥真 But never encountered its true form.

私願不果 My private desire remained unfulfilled,

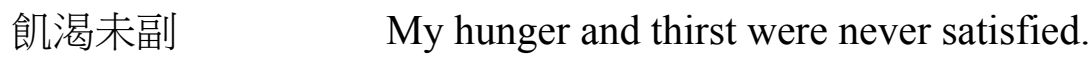

"A high mountain and a great thoroughfare" is another allusion to a Shi jing poem, in this case the poem “Ju xia" 車鹤, a poem that is traditionally interpreted as an officer's expression of joy at the prospect of obtaining a beautiful and virtuous bride for his king. The phrase is taken from the last stanza of the poem, and, in a convoluted interpretation typical of the Han commentators, is understood as a metaphor for the virtue of the ancients admired by the king once the king comes under the influence of his virtuous queen. ${ }^{34}$ What deserves notice is that, through the use of such a phrase, Cao Pi once again creates a direct relation between jade and virtue, and reiterates the symbolic meaning of a precious jade through deliberate echoes of the classical tradition. More importantly, he places himself in the position of political authority such

${ }^{34}$ Mao shi 14.484 . 
as that of a king, and the apparently modest claim - "Although my virtue is not that of a noble man"- produces, by way of negation, the very parallel between Cao Pi himself and a noble man figured as a precious jade.

The Shi jing poem speaks of the desire for a beautiful bride; Cao Pi's passage cited above speaks of his desire for a beautiful jade. Both desires are articulated in the framework of "virtue." Cao Pi's phrasing throughout this passage echoes not only the Shi jing poem seeking a worthy mate but also the political discourse of seeking worthy advisors. The keyword linking the material, erotic, and political spheres is the phrase "hunger and thirst." Noticeably, the Shi jing poem contains a couplet: "It was not hunger or thirst I felt; / I longed for an encounter with [her] virtuous words” 匪饑匪渴, 德音來括. The couplet is ambiguous as to the exact rhetorical function of the phrase "hunger and thirst": Zheng Xuan explains that even though the officer was hungry and thirsty while fetching the beautiful bride for his king, he did not feel hungry or thirsty because he was so keen to bring her back. ${ }^{35}$ Alternatively, "hunger and thirst" could also be regarded as a metaphor for the desire for the virtuous and beautiful bride.

The use of the phrase "hunger and thirst" to describe the ruler's desire for worthy men is not at all uncommon in contemporary political discourse. Zhang Hong 張紘 (151-211), a southerner who had served under Cao Cao for some time, states in his letter to his son that the longing of a wise ruler for worthy men is "like hunger and thirst." ${ }^{36}$ Ying Yang 應瑒 (d. 217), in a poem composed at a banquet given by $\mathrm{Cao} \mathrm{Pi}$, exhorts his colleagues to respect their positions

\footnotetext{
35 Ibid.

${ }^{36}$ Quan hou Han wen 86.941.
} 
in order to "answer your [Cao Pi's] concerns of hunger and thirst." ${ }^{37}$ In Cao Pi's own discussion of Emperor Wen of the Han, he describes the Han emperor as follows: "Emperor Wen's eager desire for worthy men was stronger than hunger and thirst; his employment of them was speedier than going with the current." ${ }^{38}$ When Cao Pi's desire for a beautiful jade is described in the same terms, the jade takes on a symbolic value much higher than its material value. While Fan Sui compares a worthy man to a (figurative) beautiful jade, Cao Pi is comparing a (real) beautiful jade to a worthy man.

There are some further twists and turns in Cao Pi's final attainment of the object of his desire. According to Wei lue, when Cao Pi heard of the jade in Zhong Yao's possession, "he wanted to have it, but found it hard to speak of it publicly, so he asked the Marquis of Linzi in private to convey his wish to Zhong Yao through someone else." ${ }^{39}$ Here is Cao Pi's version of the event:

近日南陽宗惠叔Ｌately, Zong Huishu of Nanyang mentioned that ${ }^{40}$

稱君侯昔有美玦 Your Lordship had once come into possession of a fine jade ring.

聞之驚喜 I was both surprised and overjoyed upon hearing of this,

笑與拉會 And I clapped my hands in laughter.

當自白書 I should have written you in person,

\footnotetext{
${ }^{37}$ Ying Yang, "Attending at a Gathering Held By the Leader of Court Gentlemen for Miscellaneous Uses at Jianzhang Terrace”侍五官中郎將建章臺集. Xian Qin Han Wei, p. 360.

${ }^{38}$ Quan sanguo wen 8.1098.

${ }^{39}$ Sanguo zhi 13.396, cited in Pei Songzhi's commentary. The Marquis of Linzi refers to Cao Zhi.

${ }^{40}$ Zong has a variant, Song 宋, in Yiwen leiju.
} 
恐傳言未審烈 But I was worried that hearsay might not be accurate,

是以令舍弟子建 Therefore I asked my younger brother Zijian

因荀仲茂時從容喻鄙旨 To convey my sentiments through Xun Zhongmao at leisure.

乃不忽遺 You did not neglect my wish,

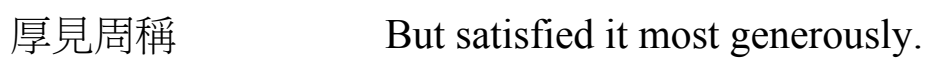

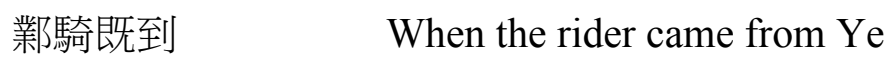

寶玦初至 And the precious jade ring first arrived,

捧匣跍發 I held the case with both hands, straightened up my back while on my knees to open it-

五內震駭 My five inner organs were shocked and stunned,

繩窮匣開 For as the rope was unwound to its end and the case opened,

爛然滿目 A brilliance filled my eyes.

猥以蒙鄙之姿 I, with my ignorant and base demeanors,

得睹希世之寶 Was able to see a treasure rare to find in the world,

不煩一介之使Ｗithout troubling a single emissary,

不損連城之價Ｗithout paying the price of many cities.

既有秦昭章臺之觀 While I possess the view enjoyed by King Zhao of Qin on Zhang Terrace, 而無鹳生詭奪之註 I never needed to perform Master Lin’s deceptive snatching.

Cao Pi describes his reception of the jade with much theatricality. His initial reaction to the information about the jade-laughing, clapping — might be very physical, even loud, but is 
nothing compared to his reaction upon actually seeing the jade. To straighten up one's back while sitting (i.e., being on one's knees) is a gesture that indicates great attention and/or respect. In sharp contrast with the sensuous language of colors and images used to describe beautiful jades earlier in the letter, he says nothing about the physical appearance of this jade; instead, the only term he uses is lanran, "brilliant," a term depicting light. The rhetorical effect thus created is striking, as this jade is elevated to a level of ethereal beauty far above the norm of precious jades, and Cao Pi is apparently so dazed and overwhelmed by its splendor that he loses his ability for words. This prompts us to revisit his earlier remark that he had been seeking for years without encountering the "true form" (zhen 真) of a precious jade: the term, zhen, is the same term for immortal beings.

The phrase, "the rope was unfastened and the case opened up," on a verbal and structural level evokes a sentence from Shi ji that is so famous for the scene it depicts that it has become a common saying in the Chinese language: "The King of Qin opened the map; when the map was unrolled to its end, the dagger appeared” 秦王發圖, 圖窮而七首見. ${ }^{41}$ This is of course the scene of the King of Qin—-later the First Emperor of Qin—-receiving the map of the rich land that was given to Qin as a gift from the King of Yan; but the gift-bearer, Jing Ke 荆軻, turned out to be an assassin who made a failed attempt on King of Qin's life. The verbal echo in Cao Pi's letter is no doubt meant to be humorous and ironic; nevertheless, it draws attention to the common issue of desire and power underlying gift receiving in both cases.

Cao Pi's modest claim about his "ignorant and base demeanors" is undercut by his selfalignment with yet another Qin ruler, King Zhao, who was none other the recipient of Fan Sui's letter cited earlier. What deserves note is Cao Pi's changing reference to the role played by Lin

\footnotetext{
${ }^{41}$ Shi ji 86.2534. The common saying is tuqiong bixian 圖窮七見.
} 
Xiangru in the recovery of He's Jade: earlier in the letter, Cao Pi praises Lin Xiangru for remaining "steadfast to principle;" but now he portrays Lin Xiangru's recovery of the jade in a negative light (“deceptive snatching”). It seems that in describing his own coming into possession of Zhong Yao's jade, Cao Pi is wavering between identifying himself with King Zhao of Qin and with Lin Xiangru. The desire to represent himself as a ruler prompts him to choose the former identification, albeit (as he emphatically points out) without having to use the former's ruses and pay the price, even though the claim that he did not have to deploy a single emissary contradicts the fact that he had indeed deployed, not one, but two emissaries-Cao Zhi and Xun Zhongmao. And yet, his reference to Lin Xiangru, the crafty protector of "He's Jade" against the Qin, seems to bespeak his anxiety about the manner in which he acquires Zhong Yao's jade.

With this unsolved rhetorical conflict Cao Pi brings his letter to an end. As if to forestall any accusation that he has "deceptively snatched" Zhong's jade, he stresses its nature as a "bountiful gift"-in other words, something freely given; he also presents Zhong with a return gift.

嘉貺益腆

敢不欽承

謹奉賦一篇

以讚揚麗質

丕白
Your bountiful gift is rich and magnificent,

How dare I not receive it with deference?

Now I respectfully present you with a poetic exposition, In order to praise its beautiful substance.

Pi lets you know. 
Only a fragment of Cao Pi's poetic exposition on the jade is still extant. ${ }^{42}$ The fragment is quite striking and deserves to be included here:

有昆山之妙璞 There is a marvelous uncut jade from the Kunlun Mountain, 產曾城之峻崖 $\quad$ produced under the steep cliffs of the Tiered Wall. ${ }^{43}$

嗽丹水之炎波 It is washed in the fiery waves of the Cinnabar River, 蔭瑤樹之玄枝 and shaded by the black boughs of the Jasper Tree. ${ }^{44}$ 包黃中之純氣 Holding within the pure aura of the Yellow Center, ${ }^{45}$ 抱虛靜而無為 it embraces empty quietude and non-action. 應九德之淑懿Ｃorresponding to the beauty of the Nine Virtues， 體五材之表儀 ｉt embodies the manifestations of the Five Elements. ${ }^{46}$

The jade is praised for its celestial origin from the mythical land, a statement that corresponds to the indication in the letter that the jade transcends the standard precious jade of the mortal world. More importantly, the jade is shown to incorporate four colors: it is washed in the "Cinnabar River" and shaded by the "black boughs" of the Jasper Tree; the Yellow Center is

\footnotetext{
${ }^{42}$ Yiwen leiju 67.1186.

${ }^{43}$ Kunlun Mountain is the legendary dwelling place of immortal beings and the Tiered Wall is its highest peak.

${ }^{44}$ Many rivers are known as the Cinnabar River. See Shanhai jing, 16, 25, 27, 41, 90. Jasper Tree grows on the Kunlun Mountain. Huainanzi 4.133.

${ }^{45}$ The "Yellow Center" refers to the heart, which, according to the theory of five elements and five colors, occupies the center and thus belongs to the element of earth and possesses the color of yellow.

${ }^{46}$ There are various theories of what the Nine Virtues are. The Five Elements are: metal, wood, water, fire and earth.
} 
a term for the human heart, the center of the five inner organs that is believed to correspond to the yellow "Earth" element of the Five Elements; finally, the color white is implied in the Daoist statement about "empty quietude and non-action," evoking a phrase from Zhuangzi: "A empty chamber gives rise to whiteness [i.e., a bright light]” (Xu shi sheng bai 虛室生白). ${ }^{47}$ Thus the four colors of white, black, red, and yellow, each of which characterizes an individual jade in the book on jade Cai Pi has read, all find their expression in one single jade that embodies completeness and ultimate perfection.

Zhong Yao loses his jade but acquires a literary representation of his jade as a return gift. He knows, however, that the real gift from Cao Pi is something else. His reply makes his gratitude quite clear.

I once had the honor, of which I was completely unworthy, to serve near the throne, and was given this penannular jade ring. The elders from the Directorate for Imperial Manufactories, who were familiar with objects from old times, commended its pattern and texture, and predicted that it would eventually find its rightful place. However, I thought Your Highness must have far more precious jades in your possession, so I held it in contempt and did not present it to you. It is my fortune that Your Highness should lower yourself to express approval of it, which truly delighted me. In the past, Mr. He was solicitous and thoughtful, loyal and honest; I, on the other hand, had to wait for your instruction first [before presenting the jade to you], and for this reason I feel deeply ashamed.

\footnotetext{
${ }^{47}$ Zhuangzi jishi 2.150 .
} 
昔忝近任, 并得賜玦。尚方耆老頗識舊物, 名其符采, 必得處所。以為執事 有珍此者，是以鄙之，用未奉貢。幸而紆意，實以悅懌。在昔和氏殷勤忠篤， 而缶待命, 是懷愧恥。

While Cao Pi makes generous use of the classical and literary tradition in speaking of jade, Zhong Yao only cites the story of Bian He. The ability to appreciate a beautiful jade and that to appreciate a worthy man are connected explicitly in the Bian He story, and the latter ability is a defining quality of a wise ruler. Thus Zhong Yao is implicitly acknowledging Cao Pi as a good ruler for his acuity of perception; he also apologizes deeply for his own failure as a subject, who should have presented the jade sooner without prompting.

What is most remarkable about this letter is the fact that Zhong Yao is thanking Cao Pi for taking his jade, and we must not regard this as a mere rhetorical flourish. The jade had been completely obscure while it was in Zhong Yao's possession, and after it was transferred to Cao $\mathrm{Pi}$, it fell into oblivion again; for a brief moment, however, during its transition from one owner to another, it shone forth with a dazzling brilliance created by Cao Pi's letter. Without Cao Pi's letter, we would never have known anything about the jade or about Zhong Yao's one-time ownership of the jade. Paradoxically, Zhong's ownership is only manifested through the very loss of his possession, as Cao Pi has made Zhong Yao the owner of the jade by taking it from him and expressing, in a well-crafted letter, his gratitude for the "gift." Cao Pi's desire for the jade also produces a surplus value inscribed on the material object that is brought out by his letter. In other words, Cao Pi's letter augments the value of the jade many times its original worth, whatever it has been. Georg Simmel (1858-1918), the German sociologist, accentuates the psychological aspect of economic exchange by stating, 
Exchange takes place not for the sake of an object previously possessed by another person, but rather for the sake of one's own feeling about an object, a feeling which the other previously did not possess. The meaning of exchange, moreover, is that the sum of values is greater afterward than it was before, and this implies that each party gives the other more than he had himself possessed. ${ }^{48}$

This aptly describes the exchange taking place between Cao Pi and Zhong Yao.

With its symbolic value, beautiful jade figured as worthy man would ultimately contribute to the expansion of Cao Pi's political capital. Cao Pi needed to gather and collect, and thus to end the circulation of a precious object—or a talented man—by possessing it/him; a good example is his competition with his brother Cao Zhi for "having” Handan Chun 邯鄲淳. ${ }^{49}$ As Fan Sui's letter to King Zhao of Qin suggests, hoarding is good for the prince but bad for the courtier. And yet, the prince must also balance the economy by bestowing gifts. As the medievalist A. J. Gurevich argues, "Generosity is an inseparable trait of the monarch," who must distribute his wealth to retain "social influence." ${ }^{50}$ While costly material gifts, land and titles are no doubt necessary, the prince's gifts do not have to always possess a high economic value — as long as they possess a high symbolic value. Among Cao Pi's many extant missives to Zhong Yao, two are gift letters: in one case, he gave Zhong Yao a bouquet of chrysanthemum flowers; in

\footnotetext{
${ }^{48}$ Simmel, "Exchange," 44.

${ }^{49}$ Wei lue, cited in Pei Songzhi's commentary, Sanguo zhi 21.602. The verb used for Cao Zhi's asking for Handan Chun's service is to “seek” (qiu 求), the same term used by Cao Pi for jade in his letter.

${ }^{50}$ Gurevich, Categories of Medieval Culture, 252, 249.
} 
another case, a "Five-Tastes Cauldron." In each case the letter is crucial for foregrounding the symbolic value of the gift.

The chrysanthemum letter is translated as follows: ${ }^{51}$

Years and months come and go, and suddenly it is the ninth day of the ninth month again. "Nine" is a yang number; now that both month and day happen to correspond to it, people cherish the name [of the "Double Ninth"] and believe it contributes to permanence. ${ }^{52}$ For this reason imperial banquet and sumptuous parties are held on this day. This month matches the musical pitch of "No Emergence," which means that none of the various trees and plants comes out and grows. ${ }^{53}$ And yet, the sweet-smelling chrysanthemum alone blooms profusely. If not for holding within the pure harmony of heaven and earth, and embodying the gentle energy of fragrant virtue, how could it be like this? Henceforth, when Qu Ping lamented his gradual aging, he longed to ingest the fallen blossoms of autumn chrysanthemum. ${ }^{54}$ For sustaining one's body and prolonging one's life, nothing is more precious than this flower. I respectfully present you with a bouquet to help with the method of Pengzu. ${ }^{55}$

\footnotetext{
${ }^{51}$ Yiwen leiju 4.84.

${ }^{52}$ That is, nine (jiu 九) puns with “permanence” (jiu 久).

53 “'The pipe of the ninth month is called 'Wu she.' 'She' means emergence. 'Wu she' means that at the time the yang energy all rises up and myriad things are withdrawn and no longer come out” 九月之管名為無射, 射者出也, 言時陽氣上升, 萬物收藏無復出也. Jin shu 22.679.

${ }^{54}$ This refers to a passage from the poem Li sao 離騷 attributed to Qu Yuan 屈原 (Qu Ping).

${ }^{55}$ Pengzu was famous for his legendary longevity.
} 
歲往月來, 忽復九月九日。九為陽數, 而日月並應。俗嘉其名, 以為宜於長

久, 故以享宴高會。是月律中無射, 言辜木庶草無有射而生。至於芳菊, 紛

然獨榮。非夫含乾坤之純和, 體芬芳之淑氣, 孰能如此? 故屈平悲再苒之將

老，思食秋菊之落英。輔體延年，莫斯之貴。謹奉一束，以助彭祖之術。

The ingestion of chrysanthemum flowers is supposed to contribute to health and longevity. The gift of chrysanthemum flowers on the "Double Ninth" conveys Cao Pi's good wishes for Zhong Yao. Cao Pi also invests the flowers with symbolic meaning, evoking the metaphorical value of the flower as a figure of virtue in the poem $L i$ sao attributed to Qu Ping, better known as Qu Yuan. While Qu Yuan was supposedly lamenting his alienation from an unwise king in the $\mathrm{Li}$ sao, Cao Pi inserts himself in the position of a wise ruler who knows how to treat his worthy ministers.

The Five-Tastes Cauldron is a ritual vessel divided into five segregated sections, with each section reserved for cooking one flavor. After Cao Pi was named heir by Cao Cao, Zhong Yao presented the mould of a Five-Tastes Cauldron to $\mathrm{Cao} \mathrm{Pi}$, who subsequently had a cauldron made on the mould and gave the cauldron to Zhong Yao with the following letter. ${ }^{56}$

In the past, the Yellow Emperor had three tripods, and the Zhou had nine precious cauldrons; but they each had only one body that was used to produce one flavor. How could they compare to this $f u$ vessel that allows five flavors to emit aromas simultaneously? Cooking in a tripod is to feast the heavenly god above and to nourish the sage and worthy. In illuminating virtue and soliciting blessings,

\footnotetext{
${ }^{56}$ Sanguo zhi 13.394-395.
} 
nothing could be more marvelous. Therefore, only a Grand Man can produce such a vessel, and only such a vessel is suitable for great virtue. Now this marvelous $f u$ even exceeds the beauty of a tripod. The Zhou minister in charge, Kaofu of the state of Song, Kong Kui of Wei and Wei Ke of Jin: these four courtiers had had their names carved on bells and tripods on account of their eminent achievements and virtue. Your Highness respectfully serves the Great Wei to augment the sagely transformation of the common folk. Speaking of magnificent virtue, none could compare with you. This is truly what the Chamberlain for Ceremonials should write an inscription for and have it carved on the sacrificial vessels in the ancestral temple. Therefore I have composed this inscription and had it carved on the mouth of the $f u$. I hope it will be able to give adequate praise of your great merit and immortalize it.

昔有黃三鼎, 周之九寶, 咸以一體使調一味, 豈若斯釜, 五味時芳? 蓋鼎之 烹䬹, 以饗上帝, 以養聖賢, 昭德祈福, 莫斯之美。故非大人, 莫之能造; 故非斯器, 莫宜盛德。今之嘉釜, 有逾茲美。夫周之尸臣, 宋之考父, 衞之 孔悝, 晉之魏顆, 彼四臣者, 並以功德勒名鍾鼎。今執事寅亮大魏, 以隆聖 化。堂堂之德, 於斯為盛。誠太常之所宜銘, 彝器之所宜勒。故作斯銘, 勒 之釜口, 庶可贊揚洪美, 垂之不朽。

This letter bears a remarkable similarity to Cao Pi's jade letter in its rhetorical strategies, most notably its evocation of the classical and literary tradition, and its enumeration of examples from the past serves only to accentuate the superiority, completeness, and perfection of the present object. The tone of the letter is, however, much more confident and straightforward. 
Although the "Great Wei" was still a feudal fiefdom rather than a dynasty at the time of writing, Cao Pi, the newly designated heir apparent, was already speaking from the position of imperial authority, this time not nearly so subtly as in his jade letter.

\section{A Man of Taste}

The last two letters cited in the previous section both have to do with food:

chrysanthemum, rather than an object of aesthetic appreciation, is to be ingested; the Five-Tastes Cauldron, like all the impressive bronze tripods from the classical period, is basically a cooking utensil, considered in modern Chinese pop culture as the ancestor of the "hot pot." Unlike his father Cao Cao, Cao Pi tried to represent himself as a man of refined taste, in food, drink, and clothes. It was not just a matter of personal difference, but also a matter of different political situation. Cao Cao, who himself came from a less than illustrious background, was eager for the endorsement of old families such as Yang Biao's $;{ }^{57}$ but in a time of political instability and civil war, the service of talented people, regardless of their social status, was much more important to him. If the old families did not support him, he would not hesitate to use brutal force. His decision to execute Kong Rong 孔融 (153-208), an eminent member of the elite and the twentieth-generation descendant of Confucius, was a good example of his policy. ${ }^{58} \mathrm{He}$ also issued several famous directives about seeking talented men regardless of their moral standing. ${ }^{59}$

\footnotetext{
${ }^{57}$ Cao Cao's father, Cao Song 曹嵩 (d. 193), was the adopted son of a eunuch. Sanguo zhi 1.1. 
As a dynasty founder ruling over a unified and stabilized north China, Cao Pi needed prestige and the backing of old families more than his father did; contending with the kingdom of $\mathrm{Wu}$ in the southeast and the kingdom of Shu in the southwest, he must also establish political legitimacy and cultural superiority — the two being regarded one and the same - over his rivals. What Cao Pi sought was a cultural aura, the aura of a "noble man” (junzi 君子). He prized himself on being a man with discernment, not just in the sense of recognizing worthy men, but also in the sense of possessing a sophisticated taste in literary, sartorial, and culinary matters.

One way of establishing himself as an authority in such matters is to liberally offer appraisal of literary writings, clothes, food, and drink. Cao Pi's attempt to represent himself as a judge of literary talents is best manifested in his "Discourse on Literature” (“Lun wen” 論文), which has been well translated and discussed. ${ }^{60}$ His statement on sartorial and culinary tastes is less known and deserves to be quoted here:

Only someone from a family of gentry for three generations understands clothes; only someone from a family of gentry for five generations understands food and drink. This just goes to show how difficult it is to know anything about clothes, food, and drink.

\section{三世長者知被服, 五世長者知飲食, 此言被服飲食難曉也. ${ }^{61}$}

\footnotetext{
60 "The Discourse on Literature," included in the Wen xuan, is excerpted from a much longer treatise on literature in Cao Pi’s work known as Normative Discourses (Dian lun 典論). For a translation and discussion, see Owen, Readings in Chinese Literary Thought, 57-72.

${ }^{61}$ Yiwen leiju 67.1187. Quan sanguo wen 6.1082.
} 
In a propaganda war, Cao Pi repeatedly issued directives to his courtiers criticizing the foods and textiles of Shu and Wu. Gift exchange between the states became an occasion for flaunting wealth and power as well as disparaging one's enemy states for their inferior products and poor taste. In these cases, gift giving was indeed "a form of surrogate warfare," in which each side tried to impress and overcome the enemy state with competitive gift giving. ${ }^{62}$

In a banquet poem entitled “Grand” (“Shanzai xing” 善哉行), Cao Pi speaks of bountiful food and beautiful music being brought forth for his enjoyment. ${ }^{63}$

\section{大酋奉甘醪 The Grand Steward offered sweet ale;}

狩人獻嘉禽 The Royal Hunstman presented excellent fowl.

齊倡發東舞 Qi entertainers performed eastern dances,

秦箏奏西音 A Qin harp gave forth the tunes of the west.

有客從南來 A guest came from the south

為我彈清琴 And played the clear zither for me.

五音紛繁會 The five notes were conjoined in abundance,

拊者激微吟 The one who strummed it stirred a faint chant.

淫魚乘波聽 Sturgeons were riding the waves to listen,

踴躍自浮沈 They leapt up, diving and rising to the surface.

飛鳥翻翔舞 Birds in flight danced, soaring around,

悲鳴集北林 They sang touchingly, roosting in the northern grove....

${ }^{62}$ Curta, "Merovingian," 698.

${ }^{63}$ Xian Qin Han Wei, 393. 
We notice that music is proffered from all four directions: the eastern dances, the tunes of the west, the zither-player from the south, and finally, the singing birds in the northern grove. This effectively situates the poet himself in the center - the fifth direction - to which bounties flow from all around. The concept of the five directions, with the corresponding Five Phases, was part of the Han cosmology that was inseparable from political philosophy and state ideology, and represented the mapping of the Han empire's geography. The center is where political authority lies; in positioning himself at the center, Cao Pi takes advantage of the geographical location of the Wei on the traditional "Central Plains" (i.e., Chinese heartland in the Yellow River region) and repeatedly stresses in his writings, either explicitly or implicitly, the status of the Wei as the Central Kingdom (zhongguo). This is clearly seen in Cao Pi's gift letters to Sun Quan 孫權 (182-252), the ruler of $\mathrm{Wu}$, as well as in his communications addressed to his courtiers disparaging the local products of $\mathrm{Wu}$ and Shu.

Cao Pi's gifts to Sun Quan were all chosen with care. In a number of letter fragments, we learn that he had sent Sun Quan one piebald horse, one white marten coat, five cakes of "rock honey," and a thousand abalones. ${ }^{64}$ Whether these gifts were sent all at once is questionable, but

\footnotetext{
${ }^{64}$ The letter fragments are preserved in different places in Taiping yulan. See Taiping yulan 694.3230 (horse and marten coat), 857.3941 (“rock honey”), and 938.4301 (abalone). Probably because all three fragments mention Zhao $\mathrm{Zi}$ 趙咨 as the messenger, Yan Kejun pieced them together into one missive. Quan sanguo wen 7.1090. However, we do not know how many trips were undertaken by Zhao $\mathrm{Zi}$ and if the gifts were given to Sun Quan all at once. $W u$ $l i$ 吳歷, a historical work written by Hu Chong 胡沖 (fl. 243-80) and cited in Pei Songzhi’s commentary to Sanguo zhi, states that in the spring of 222, Sun Quan reported to Cao Pi that he had won a great military victory over Liu Bei 劉備 (161-223), the ruler of Shu; as a reward, Cao sent to Sun Quan “a marten fur coat, a set of 'Bright Light'
} 
because of the authority and power assumed in sending gifts to the head of a state, they seem to have all been sent after Cao Pi succeeded to Cao Cao or was enthroned as emperor. We will leave aside the piebald horse for the time being and examine the marten coat, the "Rock Honey," and the abalones - in other words, gifts of clothes and food.

Marten (hun 鼠軍) is popularly known as the "gray squirrel” (hui shu 灰鼠); it most likely refers to the sable, a marten species that inhabits the forest in northern China and other places across the northern hemisphere such as Mongolia and Siberia. Although sables are primarily brown in color, individuals may have a patch of fur on the throat that could be gray, white or pale yellow. A white sable coat is rarer and more valuable than a brown sable coat, but more importantly, it is an aggressively northern gift. "Rock honey" likewise is marked by its geographical associations. It is cane sugar, which originated from India but came to China through the Silk Road. The Chinese term "rock honey" might have been a translation of the Sanskrit word śarkarā, which has the meaning of gravel, grit, and pebbles, and is referred to as the “rock honey of the Western Kingdoms" 西國石蜜. ${ }^{65}$ While the Wei was well positioned geographically to carry on trade relations with Central Asian states, the Wu would not have been able to do so easily.

The case of abalone is intriguing. The History of the Southern Dynasties (Nan shi 南史) records the following story about Chu Yuan 褚淵 (435-82), a prominent Southern aristocrat: ${ }^{66}$

armor and horse(s)," and "he also had his Normative Discourses as well as his poetry and $f u$ copied out on silk and sent to Quan.” Sanguo zhi 47.1125.

${ }^{65}$ Cao Pi uses the phrase “the Western Kingdoms' grapes and 'rock honey”” 西國葡萄石蜜 in one of his letters to his courtiers. See below.

${ }^{66}$ Nan shi 28.751 . 
At the time, the land to the north of the Huai River belonged to [Wei], ${ }^{67}$ and there was no abalone in the south. Occasionally it made its way to the south, and a single piece was worth several thousand cash. Someone once gave Yanhui [i.e., Chu Yuan's style name] thirty pieces of abalone. Though Yanhui was eminent, he lived in poverty, and one of his retainers suggested that he sell the abalone, saying, "You could get a hundred thousand cash that way." Yanhui's face dropped and replied, "I regard this as food, not as a commodity; I had no idea they could be exchanged for money. I have accepted the gift begrudgingly; now, even though I am not well-to-do, how can I sell food for money!" He shared the abalone with his relatives and friends and ate them up in no time.

時淮北屬[魏], 江南無復鰒魚, 或有間關得至者, 一枚直數千錢。人有餉彥 回鰒魚三十枚, 彥回時雖貴, 而貧薄過甚, 門生有獻計賣之, 云可得十萬錢。 彥回變色曰: “我謂此是食物, 非曰財貨, 且不知堪賣錢, 聊爾受之。雖復 儉乏，寧可賣餉取錢也。”悉與親游噉之，少日便盡。

This fascinating story about gift, money, and commodity in the Southern Dynasties exemplifies A. J. Gurevich's description of the medieval noble lords' attitude toward wealth: "Wealth as seen by the lords was not an end in itself, nor was it something that should be accumulated or economic improvement or development;" rather, it was a way of widening his circle of friends and of reaffirming his power, and so it would be best to "squander it in spectacular fashion," "in

\footnotetext{
${ }^{67}$ The character "Wei" is present in the citation in Taiping yulan 938.4301. The Wei refers to the Northern Wei dynasty (386-534), not the Wei dynasty established by Cao Pi.
} 
the full glare of publicity." ${ }^{68}$ Chu Yuan's act of conspicuous consumption affirmed his noble birth and distinguished him from a profit-seeking merchant. The story also conveys the scarcity and desirability of abalone in south China in the early fifth century. We do not know if this was the case in the early third century, but no matter whether abalone was easily obtainable in the kingdom of $\mathrm{Wu}$ or not, the gift of abalone from Cao Pi, just like marten and cane sugar, was meant to demonstrate the economic power and the bountiful natural resources of the "Great Wei": the Wei had everything produced in north, south, and the Western Region.

Apparently Cao Pi had also given Sun Quan more than once the gift of horses, another northern specialty and an important military and economic asset. ${ }^{69}$ His letter accompanying the gift of two horses survives in a better shape. ${ }^{70}$

Previously the emissaries Yu Jin and Guo Jitu had spoken [to you] of the Zou Wu and Tieli horses. ${ }^{71} \mathrm{Yu}$ Jin was originally supposed to take them to you in person;

\footnotetext{
${ }^{68}$ Gurevich, Categories of Medieval Culture, 247-48.

${ }^{69}$ In contrast, Sun Quan gave Cao Pi ships, the southern equivalent of horses. This is reflected in Cao Pi's letter of acknowledgement. TPYL 770.3545. Quan sanguo wen 7.1090.

${ }^{70}$ The text used here is the Yiwen leiju version with one emendation adopted from Taiping yulan. YWLJ 93.1623624. It also appears, with some variants, in Taiping yulan 894.4102. Yan Kejun again did a reconstruction by combining those two versions. Quan sanguo wen 7.1090.

${ }^{71}$ For this sentence I have adopted the textual variant in Taiping yulan, which reads: 前使于禁及王敦去時所道騶 吾鐵驪馬. Zouwu is a mythical beast running at a very fast speed; Tieli refers to a black horse. This textual variant seems to work better than the Yiwen leiju version, because Cao Pi specifies two horses later in the letter. The phrase “wei wu”遺吾 in the Yiwen leiju version might have been a scribal error for “Zouwu” 騶吾, which was not a common term. Yan Kejun's version reads: "Previously the emissaries Yu Jin and Guo Jifu had spoken [to you] of
} 
but in case that you, General, want them sooner, Xu Feng is ordered to take them to you now. ${ }^{72}$ These two horses are Our personal mounts; they are quite tame and good at galloping. They are the best selections from several tens of thousands of horses. Truly it is pleasure to ride them. Although the Central Kingdom is rich in horses, renowned fast-running steeds are few and far between.

前使于禁郭及土所遺吾纖驪馬。本欲使禁自致之, 念將軍儻欲速得, 今故以 付徐奉往。此二馬, 朕之常所自乘, 甚調良善走, 數萬匹之極選者, 乘之真 可樂也。中國雖饒馬，其知名絕足，亦時有之耳。

The letter is remarkable in its conceit. Cao Pi first assumes that Sun Quan must be extremely eager to get the horses; then, behind the two horses loom "several tens of thousands of horses," a display of the Wei's economic and military power; finally, he observes that the Central Kingdom is "rich in horses." The last statement is framed in a modest claim, which, however, only serves to accentuate the preciousness and restricted accessibility of the horses being given, and underscores the generosity of the giver.

my Xianli horse” 前使于禁郭及夫所道吾纖驪馬. Yu Jin 于禁 (d. 221) was a Wei general. Neither Wang Dun nor Guo Jitu/Guo Jifu is attested to in other historical sources from this period.

${ }^{72}$ The desire to identify every name leads modern commentators to take Xu Feng as a reference to Xu Sheng 徐盛 and Ding Feng 丁奉, both Wu generals. It is odd to refer to one by family name and another by first name. I take Xu Feng to be one person, who might very well be a Wei courtier. This line could also be parsed as "give them to Xu to present to you." 
On the other hand, Cao Pi theatrically turns up his nose at gifts—especially food gifts— from $\mathrm{Wu}$. Wu li records that Sun Quan once gave some large oranges to Cao Pi. Cao Pi addressed a communication to his courtiers,

The south produces oranges. They are so sour that they ruin one's teeth. Sweet ones are few and far between. ${ }^{73}$ 南方有橘，酢正裂人牙，時有甜耳。

Ironically, apparently Cao Cao had once tried to have some orange trees transplanted to the Copper Bird Park in the city of Ye (in modern Hebei), but the botanical venture of the political and military genius turned out to be disastrous. According to Cao Zhi's " $F u$ on Oranges" (“Ju fu” 橘賦), the orange trees all died in the cold climate of north China. Calling orange a "precious tree," Cao Zhi laments: "I stroke its slim branches and heave a sigh, saddened by how difficult it is to transform plants and trees” 拊微條以歎息, 哀草木之難化. ${ }^{74}$ The lament sounds faintly comic because of its cosmic proportions, with hua implying the moral transformation of the common folk exercised by the Confucian monarch, even though Cao Zhi probably did not see the humor of it.

In Cao Pi's collection there are several communications addressed to his courtiers that disparage the food products of $\mathrm{Wu}$ and commend those of the "Central Kingdom." These documents, referred to as “edicts” (zhao 詔) in their encyclopedic sources because of Cao Pi’s

\footnotetext{
${ }^{73}$ TPYL 966.4417. Yiwen leiju 86.1477.

${ }^{74}$ Quan sanguo wen 14.1129.
} 
status as emperor, effectively function as public letters. ${ }^{75}$ These "edicts" are texts on the margins of the amorphous genre of "letter," and it is entirely conceivable that they were issued with the full intention of receiving rejoinders from the courtiers that chime in with His Majesty's wise judgment, although the imperfect textual record from this period prevents us from seeing the rejoinders today. ${ }^{76}$ One such edict from Cao Pi reads:

The south produces longans and lychees; how can they compare with grapes and rock honey of the western kingdoms? They are quite sour, and their taste is inferior even to that of the ordinary date of the Central Kingdom, not to mention Anyi's dates presented to the throne. ${ }^{77}$

\footnotetext{
${ }^{75}$ For the challenge posed by letters for genre typology across cultures, see Antje Richter's lucid analysis in her study, Letters and Epistolary Culture, pp. 38-40. While a letter was known by many names in early medieval China, varying by particular circumstances and the relationship between letter writer and addressee, what constitutes a "letter" has remained constant across time. I find the definition of a "letter" given in Richter's study pertinent and useful: "It is a communication written on a tangible medium by one historical person and addressed to another (or, as the case may be, by one narrowly circumscribed group to another), which, in order to reach its spatially removed addressee, undergoes some form of physical transmission involving a third party and is, more often than not, part of an exchange." Richter, Letters and Epistolary Culture, p. 37.

${ }^{76}$ A later example is that in the early sixth century Emperor Wu of the Liang (464-549; r. 502-549) entrusted the monk Fayun 法雲 (467-529) to disseminate his rebuttal of a minister Fan Zhen’s 范縝 (ca. 450-510) anti-Buddhist treatise through letters, which received more than sixty rejoinders from princes and courtiers. The correspondences are all preserved in Hongming ji 弘明集, a sixth-century collection of writings on Buddhism. See Tian, Beacon Fire and Shooting Star, pp. 59-60.

${ }^{77}$ YWLJ 87.1486.
} 
An entry cited in Taiping yulan partially overlaps with the quotation above but includes an additional remark:

The south produces longans and lychees; how can they compare with grapes and rock honey of the western kingdoms? Now We bestow the lychees on civil and martial officers, so that they shall all know this fruit has an insipid flavor. ${ }^{78}$ 南方有龍眼荔支，寧比西國蒲陶石蜜乎? 今以荔支賜將吏，啖之則知其味薄 矣。

Another communication contrasts the best southern rice unfavorably with the best rice of the north:

To the south of the Yangzi River only Changsha claims to have good rice, but how could they even hold a candle to the non-glutinous rice of Xincheng [in modern He'nan]? When you cook it in the direction of the wind blowing, you can smell its fine aroma from five leagues away. ${ }^{79}$

江表唯長沙名好米, 何時比新城粳稻也? 上風炊之, 五里聞香。

\footnotetext{
${ }^{78}$ TPYL 971.4438.

${ }^{79}$ TPYL 839.3882. Also in YWLJ 85.1449.
} 
Yet another communication sings the praises of the grape:

There are many kinds of precious fruit from the Central Kingdom. Let us now speak of the grape for you. When the vermillion summer is transitioning into autumn but the remaining heat still lingers on, one gets drunk and wakes up with a hangover, and eats grapes covered with dews. They are sweet but not cloying, crisp but not acerbic, cool but not cold; with an enduring flavor and abundant juice they get rid of irritation and relieve nausea. One can also use grapes to make wine, which is sweeter than ale. One becomes drunk from it easily but recovers just as easily. Just talking about it makes one's mouth water, not to mention actually eating it. How could fruits from other places match it? ${ }^{80}$ 中國珍果甚多, 且复為說蒲萄：當其朱夏涉秋, 尚有餘暑, 醉酒宿醒, 掩露 而食, 甘而不䬼, 脆而不酸, 冷而不寒, 味長汁多, 除煩解 䬼。又釀以為 酒, 甘于麥藮, 善醉而易醒。道之固以流羡咽唾, 况親食之耶? 他方之果, 寧有匹者?

The most notable thing about the grape letter is the distinction made between the "Central Kingdom" and “other places" (tafang 他方), although the grape is no more of a native product of the "Central Kingdom" than cane sugar. All three communications cited above use rhetorical questions to dramatically emphasize the author's point of view and leave little room for any counter argument. Unlike letters exchanged between equals, a public letter addressed by a ruler

\footnotetext{
${ }^{80}$ TPYL 972.4440. For another translation, see Knechtges, “Gradually Entering the Realm of Delight,” 238.
} 
to his courtiers making a point usually expects a simple and positive response, but a response it expects nevertheless.

In such letters Cao Pi also criticizes the textiles of Wu and Shu. "The south of the [Yangzi] River produces hemp cloth; how could it compare with silk, gauze, damask and chiffon?" ${ }^{81}$ He expresses frustration with the unreliability of the famous Shu brocade: "The Shu brocade I have obtained at different times is never consistent in quality. It is quite shocking." He belittles the gold foils used to decorate fabrics from Shu: "The gold foils from Shu that have come to Luoyang are all of a poor quality. The products of those outlying regions have nothing but an undeserving reputation." ${ }^{82}$ He gives a summary statement: "For precious objects, one must look to the Central Kingdom." 83

Cao Pi freely dispenses his opinions regarding food and clothes. In one communication he extols the pear of Zhending (in modern Hebei): “Zhending's pears presented to the throne are as large as a fist, sweet like honey and crisp like icicles. They can relieve irritation and slake thirst. ${ }^{, 84}$ He also passes on to his court the unflattering assessment of Shu food products made by a former Shu general: “According to Magistrate Meng of Xincheng, Shu piglets, lamb, chickens and ducks all have an insipid flavor, and that is why the Shu people love to use sugar and honey

\footnotetext{
81 “江東爲葛, 寧比羅䊵綺縠?” TPYL 816.3758.

82 “前後每得蜀錦殊不相比, 適可訝...蜀薄來至洛邑, 皆下惡, 是為下土之物, 皆有虛名.” TPYL 815.3753.

83 “夫珍玩必中國.” YWLJ 67.1187.

84 “真定御梨, 大若拳, 甘若蜜, 脆若凌, 可以解煩釋渴.” TPYL 969.4429.
} 
when they cook." ${ }^{85}$ In a letter to a courtier Liu Ye 劉曄 (d. after 234), Cao Pi teases him that “Mr. Liu's cap is slightly on the short side, resembling that worn by a country bumpkin." ${ }^{\text {}}$

Liu Ye was, however, far from a "country bumpkin.” He was a scion of the imperial house of the Han. Cao Pi, the descendant of a son of a Han palace eunuch, turned the table around by representing himself as a true connoisseur of food, drink, and clothes. Tirelessly writing epistles to his courtiers as well as to his opponents, he sent them strategically chosen gifts for display and persuasion. Both the gift of his own writings, copied out on expensive silk, and that of costly material objects were meant to demonstrate the cultural power and political legitimacy of the Wei regime, which was repeatedly promoted as the center, the gathering place of cultural and material resources. Through passing literary, culinary, and sartorial judgment in his letters, Cao Pi showed himself to be the central figure in the center, a man of fine taste.

\section{Relocation}

In the foregoing sections we have discussed a number of letters accompanying gifts or expressing thanks for gifts from the turn of the third century. Early medieval gift letters went into

\footnotetext{
85 “新城孟太守道蜀肫羊鶏煦味皆淡, 故蜀人作食, 喜著飴蜜, $T P Y L$ 857.3942. The Magistrate of Xincheng was Meng Da 孟達 (d. 228), who capitulated to Wei in early 220. Thanks to this remark, we learn that early medieval Sichuan cuisine was probably rather sweet. It was apparently not only devoid of the hot taste of the chili pepper of the New World, but perhaps not even "numbing," $m a$ 麻, a sensation in the mouth not unlike the effect of oral anesthesia achieved by the native Chinese huajiao 花椒 or fagara. See Knechtges' discussion of the huajiao in "Food and Drink," 233.

86 “劉生帽裁製微不長，有似里父之服.” TPYL 687.3196.
} 
two distinct, though related, directions in the fifth century: one is the writing of verse epistle regarding gift giving and receiving; the other is the transformation of a prose letter form called $q i$ 啟 or qishi 啟事 into an elaborate “thank-you note." Although the former had a powerful impact on the later tradition, in the fifth and sixth century the dominant form of expressing thanks for gifts from a superior was the latter. While verse epistle regarding gift giving and receiving may be directed to a social equal, a $q i$ is used to express thanks to a superior, often a member of the royal family. $Q i$ had begun as a simple, straightforward communiqué about official business, not limited to the expression of gratitude for gifts. In its function as a thank-you note, however, it gradually became more and more refined and flowery, culminating in a well-crafted piece of parallel prose in the first half of the sixth century.

In later times writing a poem to give thanks for a gift was extremely common, but judging from the textual evidence we have, this practice seems to start flourishing only in the late Southern Dynasties, i.e., the fifth and sixth century. Earlier Cao Pi had sent a poetic exposition (fu) to Zhong Yao to thank him for the gift of jade, but by now poetry seems to have become the preferred genre as a return gift. The thank-you poem is also an off-shoot of the verse epistle known as zengda shi 贈答詩 (“presentation-reply poetry”), for when a late Southern Dynasties poet addresses a thank-you poem to a friend, s/he often seems to be responding to the friend's poem accompanying the gift rather than to the gift alone. ${ }^{87}$

\footnotetext{
${ }^{87}$ See Zeb Raft's essay on zengda shi in the four-syllable line, "The Space of Separation: Medieval Chinese Poetry of 'Presentation and Response,”’ in this volume. Also see Zhao Yiwu 趙以武, Changhe shi yanjiu 唱和詩研究 (Lanzhou: Gansu wenhua chubanshe, 1997); Jiang Yaling 江雅玲, Wen xuan zengda shi liubianshi 文選贈答詩流 變史 (Taibei: Wenjin chubanshe, 1999).
} 
In a rare case, the poems from both gift donor and receiver have survived. Dao Gai 到溉 (477-548), a renowned man of letters, wrote a poem entitled "Giving a Mottled Bamboo Staff to Ren Xin'an and Presenting Him with a Poem" (“Xiang Ren Xin'an banzhuzhang yin zeng shi” 餉任新安班竹杖因贈詩). “Ren Xin’an” refers to Ren Fang 任昉 (460-508), a senior writer and scholar, who had served as Magistrate of Xin'an. Ren Fang replied with “In Response to Dao Jian’an’s Gift of Staff” (“Da Dao Jian’an xiang zhang shi” 答到建安餉杖詩). ${ }^{88}$ In most cases, however, only the poem from gift donor or receiver is still extant. For instance, Wang Yun 王筠 (481-549), a well-known court poet, sent a bouquet of chrysanthemum to Xie Ju 謝舉 (d. 548) along with a poem entitled "I Picked Chrysanthemums from My Garden to Give to Grand Councilor Xie Ju” (“Zhai yuanju zeng Xie puye Jus hi” 摘園菊贈謝仆射舉詩); on another occasion, he sent some pomegranates to Liu Xiaowei 劉孝威 (496?-549), also a renowned poet, along with an ardent poetic profession of friendship, "I Picked Pomegranates to Give to Liu Xiaowei” (“Zhai anshiliu zeng Liu Xiaowei shi” 摘安石榴贈劉孝威詩). In both cases we do not have a thank-you poem from Xie Ju or Liu Xiaowei, if they had written any. An extant poem by Wang Yun gives thanks for some plums from a colleague, with the title "In Response to the Red Plums from Yuan the Grand Master of the Palace with Golden Seal and Purple Ribbon" ("Da Yuan jinzi xiang zhuli shi” 答元金紫餉朱李詩). ${ }^{89}$

\footnotetext{
${ }^{88}$ Xian Qin Han Wei, 1855, 1599.

${ }^{89}$ Ibid., 2019, 2017, 2020.
} 
Two gift poems by a woman poet named Liu Lingxian 劉令嫻, who was Liu Xiaowei’s sister, deserve a special note. ${ }^{90}$ One is a quatrain accompanying the gift of gardenia presented to a Lady Xie, in which Liu makes a witty pun about the name of gardenia (zhizi 栀子) and "this person” (zhizi 之子): “the gardenia/this person touches my heart most of all” 栃子最關人. ${ }^{91}$ The other is a poem expressing gratitude to a Ms. Tang, an entertainer, for her gift of threaded needles. ${ }^{92}$ Threading needles was a custom observed by young women on the eve of the seventh day of the seventh month, a festival celebrating the reunion of the separated heavenly lovers, the Cowherd and the Weaving Girl. To thread needles with multi-colored threads swiftly and successfully in the moonlight on this night was regarded as a good sign for obtaining dexterity in needlework. In her poem, after giving obligatory praises of Ms. Tang's needlework skills, Liu Lingxian adds a personal touch by reflecting on her circumstances: "The widow's boudoir is devoid of silks and damasks, / Holding your gift in my hands, I feel pity for myself” 孀閨絕綺羅， 攬贈自傷㗝. Liu Lingxian was married to Xu Fei 徐悱 (495-524), himself a fine poet, who had died an untimely death while serving as administrator at Jin’an 晉安 (in modern Fujian).

Xiao Gang 蕭綱 (503-51), also known by his posthumous title Emperor Jianwen of the Liang 梁簡文帝 (r. 549-51), once sent a poem to thank the Prince of Nanping for some cherries. $^{93}$

\footnotetext{
${ }^{90}$ For women's letters in late imperial China, see Ellen B. Widmer's essay, ““'Letters as Windows on Ming-Qing Women's Literary Culture," in this volume. 
倒流映碧叢 Reversed in the currents: the reflection of a verdant grove;

點露擎朱實 Sprinkled in dewdrops, scarlet fruits held high.

花茂蝶爭來 When flowers are lush, butterflies vie to visit;

枝濃鳥相失 Amidst leafy boughs birds lose one another's tracks.

已麗金釵瓜 It is not only lovelier than the Golden Hairpin melon, ${ }^{94}$

仍美玉盤橘 But also more beautiful than the orange in the jade plate. ${ }^{95}$

寧以梅似丸 How could one compare bayberries to pellets? ${ }^{96}$

不羡萍如日 Nor do we covet the duckweed fruit as large as the sun. ${ }^{97}$

永植平臺垂 Always planted beside the Level Terrace, ${ }^{98}$

長與雲桂密 It forever remains intimate with cassias in the clouds. ${ }^{99}$

94 “Gold Hairpin” is the name of a kind of melon. See Lu Ji’s 陸機 (261-303) “Fu on Melon” (“Gua fu”瓜賦).

Quan Jin wen 97.2015.

${ }^{95}$ Orange in the jade plate is an allusion to an anonymous "old poem" from the late Eastern Han. Xian Qin Han Wei, 335.

${ }^{96}$ Bayberry is a subtropical tree, also known as Chinese Bayberry or popularly as “yumberry.” Shen Ying’s 沈瑩 (d. 280) Linhai yiwu zhi 臨海異物志 states: “Bayberry’s fruits are like pellets”楊梅其子如彈丸. Taiping yulan

972.4442. Zhang Hua’s 張華 (232-300) Bowu zhi 博物志 also states: “As for cherries, some of them are like pellets” 櫻桃者或如彈丸. Yiwen leiju 86.1479.

${ }^{97}$ When the king of Chu was boating on the river, the boatman obtained a fruit that was big, round, "red like the sun" and "as sweet as honey." No one but Confucius could identify it as the "duckweed fruit," which he said was a good omen for the king. Kongzi jiayu 2.18.

${ }^{98}$ Level Terrace was part of the Prince Xiao of Liang's park. Shi ji 58.2083. 
徒然奉推甘 In vain you have upheld the value of yielding the sweets,

終以愧操筆 For in the end I am ashamed in taking up the brush.

Like Cao Pi's $f u$ on the jade gift that begins with a portrayal of the jade's divine origin and extraordinary attributes, the poem offers a vivid depiction of the cherries replete with references to the literary tradition. It ends with a modest claim of the poet's meager talent, implying that the textual representation of the thing does not do full justice to the real thing. Just as Cao Pi's fu very much falls into the category of "poetic expositions on things" (yongwu fu 詠物賦), Xiao Gang's poem evokes the poetic sub-genre known as “poetry on things” (yongwu shi 詠物詩), which showcases a poet's erudition and descriptive power.

The genre of $q i$ as thank-you note, though a prose form, shares the characteristics of the "poetry and poetic expositions on things." As mentioned earlier, qi was an official communiqué addressed to superiors. ${ }^{100}$ The literary critic Liu Xie 劉劦思 (ca. 460s-520s) thus discusses qi in his work Wenxin diaolong 文心雕龍:

"Qi" has been very popular since the Jin dynasty, and its use overlaps with memorials (biao) and reports (zou). It is used to discuss matters of governance

\footnotetext{
${ }^{99}$ See Guo Pu's 郭璞 (276-324) encomium on the cassia tree: “The cassia grows in the southern frontier, towering above others on the high mountain....Its aura dominates a hundred kinds of medicinal plants; lush and prosperous, it rises upright into the clouds” 桂生南裔, 拔萃岑嶺...氣王百藥, 森然雲挺. Quan Jin wen 122.2158.

${ }^{100}$ According to Fu Qian's 服虔 (fl. $2^{\text {nd }}$ century) Tongsu wen 通俗文, “Official communiqués are called qi” 官信曰 啟. TPYL 595.2810. But all the extant early examples of $q i$ are addressed to one's superiors, including but not limited to the emperor, and the term qishi 啟事 (to report official business) clearly indicates reporting to superiors.
} 
and affairs of the state, so it is an alternative of the report; it is also used to decline the conferral of official titles or express gratitude for imperial grace, in which case it is a substitute for the memorial. It must be restrained and observes the rules; its pace must be swift; it must be to the point, light, and clear; it must be embellished without being excessive: these are the general principles of a $q i .^{101}$ 自晉來盛啟, 用兼表奏。陳政言事, 既奏之異條; 讓爵謝恩, 亦表之別幹。 必斂轍入規，促其音節，辨要輕清，文而不侈，亦啟之大略也。

By the time when Liu Xie wrote his Wenxin diaolong at the turn of the sixth century, $q i$ as a thank-you note had become so intricate that it seemed nothing but "excessive." Though usually brief, it is densely allusive and applies strict parallelism. Its excessiveness is also embodied in an excess of meaning: by recreating the material gift with beautiful words drawn from the literary tradition, the author of a well-crafted thank-you note endows the gift with a surplus of symbolic value that far exceeds its economic value, so that a qi, as a textual representation of the gift and a return gift, constitutes an adequate repayment for the donor's grace.

The remainder of this section will be devoted to an analysis of three $q i$ expressing gratitude for the gift of oranges written by courtiers of the Liang 梁 dynasty (501-57). The period of the Northern and Southern Dynasties was again a period of disunion; but unlike the Three Kingdoms period, the south now was dominated by a series of Han Chinese dynasties while the north was ruled by non-Han ethnic peoples. For the first time in Chinese history the south

\footnotetext{
${ }^{101}$ Liu Xie, Wenxin diaoling 23.873. For Liu Xie's work and early medieval Chinese letters, see Pablo Ariel Blitstein, “Liu Xie's Institutional Mind: Letters, Administrative Documents and Political Imagination in $5^{\text {th }}-6^{\text {th }}$ century China," in this volume.
} 
stopped being a peripheral region to the "Central Kingdom" and became established as a cultural center. The making of the south was very much a result of the successful literary and cultural programs of the sophisticated southern court, especially under the long rule of Emperor Wu of the Liang, who, along with his three talented sons, Xiao Tong 蕭統 (501-531), Xiao Gang, and Xiao Yi 蕭繹 (508-555), actively promoted cultural enterprises. The Xiao princes, especially Xiao Tong and Xiao Gang, were fascinated with Cao Pi, Cao Zhi, and their literary coterie from the Jian'an era; Xiao Tong represented the Jian'an era in his monumental literary anthology Wen xuan in such a way that the selections created an idealized image of the Jian'an, which the Xiao princes upheld as their own model. This is the background against which we must read the three orange letters, which all evoke the writings of the Cao family and, through these allusions, demonstrate the working of the contemporary cultural politics.

Liu Qian 劉潛 (484-550), better known as Liu Xiaoyi 劉孝儀, was the brother of Liu Xiaowei and Liu Lingxian. Translated below is his thank-you note to the Crown Prince for a gift of “sour-peel oranges growing by the city wall” (“Xie Donggong ci cheng pang ju qi” 謝東宮賜 城傍橘啟): ${ }^{102}$

多置守民 Many people were assigned as guards of the orange trees晉為厚秩 $\quad$ This was a lucrative office in the Jin; ${ }^{103}$

\footnotetext{
${ }^{102}$ Yiwen leiju 86.1479. The Crown Prince could be either Xiao Tong or Xiao Gang, who was designated as heir apparent in 531 after Xiao Tong's untimely death.

${ }^{103}$ According to Yang Fu's 楊孚 (fl. 77) Yiwu zhi 異物志, “Orange tree has white blossoms and red fruits. The orange fruit has an aromatic peel and tastes good. An office with the salary of three hundred bushels of grain is established in the region of Jiaozhi [modern northern Vietnam] to supervise the presentation of oranges to the throne"
} 
坐入縑素

漢譬封君

固以

俛㱜穰橙

俯連楚柚

䀂似魏瓜

借清泉而得冷
Fine silks were earned for nothing-

During the Han owning orange groves was compared to enjoying a fief. ${ }^{104}$

Indeed these oranges might

Deign to be matched with the coolie orange of the Rang Prefecture,

And condescend to claim a connection with the pomelo of Chu. ${ }^{105}$

But in no way should they be likened to the melon of Wei

That must rely on a clear spring to become cool; ${ }^{106}$

橘白華赤實, 皮馨香有味, 交阯有橘官長一人, 秩二百石, 主貢御橘. Yiwen leiju 86.1477; also cited in TPYL 626.2936, with a variant: “three hundred bushels of grain.” The Nanfang caomu zhuang 南方草木狀, authored by the Western Jin writer Ji Han 嵇含 (262-306), includes a similar entry, but with the additional information that the orange officer was established “since the time of Emperor Wu of the Han" 自汉武帝. Han Wei liuchao xiaoshuo, 265.

104 “"Those who....grow a thousand orange trees at Jiangling....possess the wealth that is equivalent of a fief of a thousand households” 江陵千樹橘......此其人皆與千戶侯等. Shi ji 129.3272. Li Heng 李衡 (fl. $3^{\text {rd }}$ century), a Wu magistrate, famously compared a thousand orange trees he owned to "a thousand wooden slaves" (ти nu qian tou 木 奴千頭) and said the orange grove would earn the family an income of over a thousand bolts of silk every year.

Quan sanguo wen 73.1444.

${ }^{105}$ Rang Prefecture was in Nanyang 南陽 (in modern He'nan). The coolie orange of Rang is lauded in Zhang Heng's 張衡 (78-139) “Fu on the Southern Metropolis” (“Nan du fu” 南都賦). Quan hou Han wen 53.768. Lü Buwei, Lüshi chunqiu 呂氏春秋 14.741: “Among fruits, the delicious ones are.... the pomelos of Yunmeng” 菓之美者.... 雲夢之柚.

${ }^{106}$ This refers to Cao Pi’s letter to Wu Zhi 吳質 (177-230), in which he recalls the pleasures enjoyed on their outings together: “We floated sweet melons in a clear spring”浮甘瓜於清泉. Quan sanguo wen 7.1089. 
峘如蜀食

待飴蜜而成甜

重似

倒影陽池

垂華金堞

信可

珍若榴於式乾

貴蒲萄於別館
And certainly they are superior to the food from Shu

That only becomes sweet with sugar and honey. ${ }^{107}$

Furthermore, ${ }^{108}$

They cast shadows in the sun-warmed moat,

Their splendid blossoms hanging over the parapet wall of metal.

Truly they are

More precious than the pomegranate of the Shiqian Palace, ${ }^{109}$

And more prized than grapes planted at royal villas. ${ }^{110}$

Liu Qian's thank-you note is a fine example of the epistolary genre of $q i$, characterized by its brevity and its use of parallelism throughout. It begins by tracing back to Han and Jin dynasties and stating the economic and political importance of the orange trees: orange groves, like a noble lord's fiefdom, confer wealth on individuals; the presentation of oranges to the throne from the farthest south also demonstrates the far-reaching power of the empire. Next, the author praises the orange as being a sort of a "better equal" to fruits of both north and south,

\footnotetext{
107 This refers to Cao Pi’s recounting of Meng Da’s report about the bland food of Shu. See Note \#81.

${ }^{108}$ Here $s i$ 似 should probably be emended to $y i$ 以.

${ }^{109}$ The Shiqian Palace was a Wei and Western Jin palace in Luoyang. Fruit trees were apparently planted in front of it. One source mentions there were two cherry trees. Yiwen leiju 86.1479. Ying Zhen’s 應貞 (d. 269) preface to his “Fu on Pomegranate” (“Anshiliu fu” 安石榴賦) states that when he was working in the Imperial Library, there was a pomegranate tree in front of the office where he was on night duty. YWLJ 86.1481.

${ }^{110}$ After grapes were introduced into China, they were “planted everywhere beside the imperial villas” 離宮別觀傍 盡種蒲萄. Shi ji 123.3174 .
} 
respectively represented by the coolie orange of the Rang Prefecture and the pomelo of Chu. This sets the stage for the next statement, which alludes to no less than two of Cao Pi's letters and disparages the foods of Shu and Wei. Such a rhetorical move not only avenges the $\mathrm{Wu}$ orange once scorned by Cao Pi but also implicitly aligns the author's position with none other than the kingdom of $\mathrm{Wu}$. The Liang courtier, however, could very well take pride in the cultural and political resources of the south, and Liu Qian ends his note with an echo of the opening lines by claiming the orange's superiority to the fruits — pomegranate and grape — cherished by the Jin and Han royalty. While pomegranate and grape were both imported exotic fruits, the orange was native to the south — as a matter of fact, grown right by the wall of the capital city. Indeed there is no need to look beyond one's own backyard.

The presence of textual references throughout the letter except in one sentence draws attention to that sentence: "They cast shadows in the sun-warmed moat, their splendid blossoms hanging over the parapet wall of metal." The "sun-warmed moat" stresses the southern facing of the moat, a positioning well suited to the growth of orange trees; it also highlights the southern origin of the orange, which is considered a yang fruit of the sun (Cao Zhi writes thus in his " $F u$ on the Orange": "It inherits the fiery energy of the great yang, and delights in the splendor of the bright sun” 禀太陽之烈氣, 嘉杲日之休光). ${ }^{111}$ In Liu Qian’s couplet, the orange blossoms (hua) are placed in the corresponding position of "reflection/shadow" (ying). Since the orange blossoms are white, there is an implied color contrast: dark shadow cast in water vs. pale, sundrenched blossoms. The black and white contrast is striking against the "metal parapet wall," with "metal" being the same word as "gold/golden-colored" (jin), the color of the orange fruit.

${ }^{111}$ Quan sanguo wen 14.1129. 
The only parallel couplet devoid of textual allusions in the letter presents a charming vignette and showcases the consummate descriptive skill of an accomplished court writer.

Another extant letter by Liu Qian is addressed to the Prince of Jin'an, Xiao Gang's title before he was named the Crown Prince in 531, in which Liu Qian thanks Xiao Gang for the gift of citrus fruit (“Xie Jin’an wang ci gan qi” 謝晉安王賜甘啟). ${ }^{112}$ The fruit is gan, sweet-peel tangerine, not $j u$, sour-peel orange; but as we will see, the author does not care much about the botanical distinction when deploying literary allusions:

便得等ight away one could

削彼金衣 Peel away its golden coat,

咽茲玉液 And drink its jasper juice. ${ }^{113}$

甘踰萍實 Its sweetness exceeds the duckweed fruit, ${ }^{114}$

冷亞水圭 Its coolness is only second to the watery jade. ${ }^{115}$

${ }^{112}$ Yiwen leiju 86.1475-476.

${ }^{113}$ Li You 李无 (44-126), “Qi kuan” 七款: “Golden coat, vermillion interior”金衣朱里. Quan hou Han wen 50.747.

"Jasper juice" usually refers to elixir.

${ }^{114}$ For the "duckweed fruit," see Note \#91.

${ }^{115}$ For “watery jade” shui gui 水圭, Yan Kejun has “a jug of ice” (bing hu 冰朢). Quan Liang wen 61.3317. Shui gui, however, might be an error for bing gui 水圭, which appears in “Fu on the Melon” (“Gua fu” 瓜賦) by Liu Zhen 劉楨, a member of Cao Pi and Cao Zhi's literary coterie: “Its sweetness exceeds the honeycomb, and its coolness is second only to the icy jade” 甘逾蜜房, 冷亞冰圭. Quan hou Han wen 65.829. These two lines, “甘踰萍 實, 冷亞冰壳,” also appear in a thank-you note attributed to Liu Jun 劉峻 (461-521), which is included in Quan 
立消煩䬼 It immediately gets rid of frustration and nausea,

頓除酩酊 And cures the hangover at once. ${ }^{116}$

追虽齊相 I snicker at the prime minister of Qi from long ago-

進不剖之實 Who ingested the fruit without cutting it open; ${ }^{117}$

遠笑魏君 I laugh at the emperor of Wei in the distant past-

逢裂牙之味 Who encountered the taste that ruined his teeth.

This letter mimics the process of the ingestion of the fruit by representing a movement from the exterior to the interior. It opens with an "opening" of the fruit, and, as the author takes in the juice of the orange, he finds it both sweet and cold, which eliminates physical and spiritual discomfort. With a renewed spirit he looks back at the minister and ruler of the past: northerners who did not know how to eat the orange properly or who "encountered" a poor specimen of the orange. He unabashedly celebrates the here and now, for his prince bestows a gift of orange far superior to the one given to the Wei ruler, and more importantly, the gift is lavished on a minister who understands how to appreciate it. Ironically, Liu Qian uses Cao Pi’s very words praising a

Liang wen 57.3286. The compiler Yan Kejun cites as his source a work on oranges, Ju lu 橘錄, written by Han Yanzhi 韓彥直 (1131-after 1178), but the attribution is not attested to in any earlier source.

116 This is an allusion to Cao Pi’s letter on the grape (see previous section).

${ }^{117}$ According to a story recorded in Shuo yuan 說苑 compiled by Liu Xiang 劉向 (77-6 B.C.E.), Duke Jing of Qi sent his minister Yanzi 晏子 on a diplomatic mission to Chu. The king of Chu gave him an orange and a peeling knife, but Yanzi ate the orange without peeling it. When the Chu king reminded him of his faux pas, Yanzi replied that it was not that he did not know he should peel the orange before eating it, but that a subject should not cut open a fruit in front of a ruler unless the ruler ordered him to do so. Shuo yuan 12.406. 
northern fruit (i.e., the grape) to extol the southern produce, but in the end the joke is on $\mathrm{Cao} \mathrm{Pi}$, who ruined his teeth on sour oranges from the southern king. The letter ends with condemning the wrong kind of opening - the fruit that was not peeled, and the teeth that were literally "cracked"- and thus comes full circle by echoing the right kind of opening at the opening.

The last orange letter to be discussed was written by Yu Jianwu 庵肩吾 (487?-551), one of the leading poets of the Liang court.

光分璇宿

影接銅峰

去青馬之迢遞

服朱閏之爽塏

楚原洪筆

頌記不遷

陳王麗藻
Its light is divided from the Northern Dipper; ${ }^{118}$

Its shadow touches the copper hills. ${ }^{119}$

Having left the distant land of the black horses, ${ }^{120}$

It grows accustomed to the sunny aridness of the vermillion barbican.

In an ode, the majestic brush of Qu Yuan of Chu

Records its refusal to relocate;

The Prince of Chen's beautiful rhapsody

${ }^{118}$ According to Chunqiu yundoushu 春秋運斗樞, a Han astrological work, “The Xuan and Shu Stars disintegrates and turns into oranges” (“Xuan Shu xing san wei ju” 璇樞星散為橘). Yiwen leiju 86.1477. The Shu Star and Xuan Star are the first and second of the seven stars of the Northern Dipper, and "Xuan Shu" becomes a general reference to the Northern Dipper.

${ }^{119}$ Yang Xiong’s 揚雄 (53-18) “Fu on the Shu Capital” (Shu du fu 蜀都賦) contains the line praising the local products of Shu: “Orange groves, copper-producing hills” (“Julin tongling”橘林銅陵). Quan Han wen 51.402.

${ }^{120}$ Ying Shao 應劭 (fl. late second century) cites a lost work, Yi Yin shu 伊尹書: “To the east of the Ji Mountain, at the place where the black horses are, there are black kumquats that ripen in summer” 箕山之東, 青馬之所, 有盧橘 夏孰. Han shu 57.2559. There is a variant for qing ma that reads qing niao (blue birds). Shi ji 117.3028. 
賦稱遙植 Claims its transplantation from afar. ${ }^{121}$

昔 In the past,

朝歌季重 Jizhong, the Magistrate of Zhaoge,

䌆賜海魚 Was only given some ocean fish; ${ }^{122}$

大理元常 Yuanchang, Chamberlain for Law Enforcement,

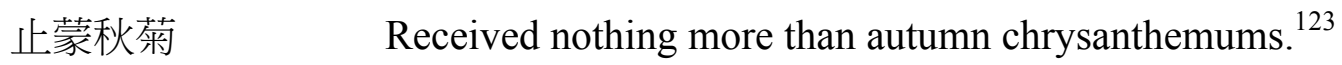

The “Ode to the Orange" (“Ju song” 橘頌), attributed to Qu Yuan, is one of the "Nine Pieces” (“Jiu zhang” 九章) in the Lyrics of Chu (Chuci). As David Hawkes notes, the orange tree "was traditionally supposed not to grow naturally anywhere north of the River Yangtze." 124 The ode opens with these lines:

This fine tree between heaven and earth,

Orange it is, settling down and becoming accustomed to the soil here.

It receives the command of heaven not to relocate,

\footnotetext{
${ }^{121}$ Cao Zhi was enfeoffed as the Prince of Chen. His "Fu on the Orange" contains the lines: "Transplanted from ten thousand leagues away, it was on display in the park of the Copper Bird”播萬里而遙植, 列銅爵之園庭. Quan sanguo wen 14.1129 .

${ }^{122}$ Jizhong is the courtesy name of Wu Zhi, a close friend of Cao Pi. He had served as magistrate of Zhaoge at one point, and during his term there Cao Pi addressed several letters to him. The gift of fish was presumably sent to him by Cao Pi.

${ }^{123}$ Yuanchang is Zhong Yao's courtesy name.

${ }^{124}$ Hawkes, The Songs of the South, 178.
} 
But only grows in the southern land.

后皇嘉樹, 橘徠服兮

受命不遷, 生南國兮

These lines from a literary classic constitute the core around which Yu Jianwu structures his letter.

Writing in the tradition of poems/poetic expositions on things, Yu Jianwu begins his letter by recounting the origin of the orange. It is a mystical place in the celestial sphere, and the golden color of the orange is implicitly conveyed in its "light," which it receives from the Xuan and Shu stars. Fascination with the interplay of reflection/shadow (ying) and light is a peculiar Liang phenomenon, ${ }^{125}$ and light is often portrayed by its opposite and negation. Sure enough, the next line in the parallel couplet turns from light to shadows, from heaven to earth, from a dazzling constellation to copper-producing mountains that cast dark shadows under the bright fruit-stars.

As the letter shifts the viewpoint from the celestial to earthly realm, the orange too is shown to have relocated. It comes to settle in the part of the mortal world that is marked by the vermillion color, that is, the fiery south. Interestingly, the humid south is not traditionally characterized as sunny and arid (shuang kai 爽塏). Jiang Yan 江淹 (444-505), an older contemporary of Yu Jianwu, uses shuang kai to depict north China in his " $F u$ on Lamenting a Thousand Leagues” (“Ai qianli fu” 哀千里賦): “Although the north of the Yellow River is sunny and arid, / [I remain steadfast] like the oranges and pomelos that do not relocate" ("Sui He'bei

\footnotetext{
${ }^{125}$ For a detailed discussion of this phenomenon, see Tian, Beacon Fire and Shooting Star, 211-259.
} 
zhi shuang kai, you ju you zhi buqian” 雖河北之爽塏, 猶橘柚之不遷). ${ }^{126}$ In his use of the compound $\mathrm{Yu}$ Jianwu may very well be focusing on the meaning of the first character, i.e., "shuang" as "brightly lit," which is an attribute of the sunny south. By such a rhetorical shift of emphasis he manages to empower the south with a positive trait that is usually associated with the north.

Once the orange settles in the south and becomes accustomed ( $f u$ 服, evoking laifu 徠服 in the "Ode to the Orange") to its soil, it finds its true home. Citing the "Ode to the Orange" and then Cao Zhi's " $F u$ on the Orange," Yu Jianwu makes a satirical jab at the Cao family. From this point on, the rhetorical move follows the same trajectory as that in Liu Qian's second letter: not only are the Xiao princes, as opposed to the Cao family, blessed with the celestial fruit native to the southern land, but the Liang courtier also receives a gift far superior to those received by the Wei courtiers Wu Zhi and Zhong Yao.

In these thank-you notes, orange becomes the locus of an empiric discourse that attempts to establish the south as a new cultural and political center vis-à-vis earlier times and the presentday rival state in the north. The Cao Wei princes, frequently alluded to in these letters, constitute the very norm and standard against which the Liang princes and courtiers measure the present; they are both the role models to be emulated and the competitors to be surpassed. The three orange letters embody the contemporary cultural politics; more importantly, with their dense allusions and rhetorical flourishes, they become a code language that can only be deciphered by insiders possessing the same level of erudition and literary training. By writing such letters to their princes, the courtiers show themselves to be men of fine taste who know how to properly savor the delicious princely gift; and the princes, in turn, are placed by these letters in the

\footnotetext{
${ }^{126}$ Quan Liang wen 33.3143.
} 
position of understanding readers who know exactly how to appreciate these delectable return gifts.

This paper considers the issue of material and symbolic economies underlying letters regarding the transfer of objects in early medieval China. While the modern gift theory, initiated by Marcel Mauss, largely deals with the gift objects themselves, I argue that the letter accompanying a gift plays a crucial role in the creation and interpretation of meaning of the gift object. Context can certainly shed much light on a gift-exchange, but the letter of the donor (and sometimes the letter of the receiver as well) helps us more than anything to decode the sign that is the material object being transferred from one person to another.

A letter also constitutes a gift in itself. When it accompanies a gift of material object, this double gifting complicates the process of exchange and circulation, and prompts us to reconsider the working of reciprocity in gift-giving. None of the gift recipients discussed in this paper is known to have sent a material return gift to the donor, but they all give back textual repayments instead. This is quite obvious in Cao Pi's thank-you letter to Zhong Yao for the gift of jade, with which he encloses a poetic exposition praising the jade, and in the sixth-century thank-you notes for the gift of oranges from the Liang princes. In other cases, one could argue that the gifts being given are already “return gifts" for services rendered. For instance, Cao Pi’s gift of chrysanthemum flowers and Five-Tastes Cauldron to Zhong Yao for being a loyal servant to the Wei, the Liang princes' gifts of oranges to their courtiers, or even Cao Cao's lavish gifts to Yang Biao, which could be read as a return gift for having had the "use" of Yang Biao's son. There is 
no need to reciprocate with material gifts in such cases, although the donor might still expect to receive a letter of acknowledgment and appreciation. Indeed, sometimes one may legitimately wonder if a prince hands out food gift to his literary courtier just for the sake of getting a wellcrafted thank-you letter in return to satisfy his own aesthetic craving. In any case, the exquisite thank-you note of the late Southern Dynasties functions just like Cao Pi's poetic exposition on the jade: it is the textual substitute for the material gift and constitutes an adequate return gift because it creates a surplus value for the gift itself.

The importance of the letter in deciphering the meaning of a gift is nowhere demonstrated so clearly as in a gift being offered under dubious circumstances with a short gift message. At the beginning of this paper I have mentioned Zhuge Liang's insulting gift of female clothes to the Wei general Sima Yi, so it is fitting to end the paper with a gift message to Zhuge Liang from none other than Cao Cao himself. The message, most likely a fragment of the original letter, is simple enough: "Now I am presenting you with five catties of cloves to convey my humble sentiments” 今奉雞舌香五斤, 以表微意. ${ }^{127}$

The clove was an exotic product from the far south. According to Ying Shao, during the Han Dynasty members of the Imperial Secretariat would keep cloves in their mouths to sweeten their breath when reporting to the emperor. He records a humorous story involving cloves. Diao Cun Э存, a senior Palace Attendant with bad breath, was given some cloves by Emperor Huan 桓帝 (r. 147-67). Not knowing what the clove was, Diao Cun thought it was poison and that he was asked to commit suicide. He went home to bid a tearful farewell to his family. When his colleagues and friends heard, they all came to visit him, and laughed heartily upon seeing the

\footnotetext{
${ }^{127}$ Quan sanguo wen 3.1070.
} 
"poison." They offered to take some of the "poison" themselves, and only then did Diao Cun recognize his ignorance. ${ }^{128}$

Cao Cao's gift of cloves to Zhuge Liang - a high-level minister serving one of his archenemies - could be subjected to various interpretations. It could be a simple demonstration of respect. Or it could be a subtle gesture to win Zhuge Liang over to Cao Cao's side: since Cao Cao remained a Han subject all his life, the cloves, which were the hallmark of a Han Secretariat Court Gentleman, could be construed as an invitation to Zhuge Liang to occupy a prestigious position at the Han court. Or it could be taken as an insult, as it implied that Zhuge Liang had bad breath — metaphorically (i.e., giving bad counsel to his lord) and/or literally. Without the context in which the gift-giving took place and without a more detailed letter accompanying the gift, we will never find out exactly what the gift meant or what it was supposed to mean, whether it was a "straightforward" gift or, since interpreting a gift symbolically was not an uncommon phenomenon in the third century, a sign that is deliberately left ambiguous and intended to elicit multiple readings. ${ }^{129}$

${ }^{128}$ Quan hou Han wen 34.666.

${ }^{129}$ A contemporary example of making symbolic interpretations of gifts can be found in the third-century historian Sima Biao’s work, Zhan lue 戰略. Meng Da, the Shu general who capitulated to Wei in 220, later had second thoughts about it. He communicated with Zhuge Liang, who tried to persuade him to come back to Shu. Meng Da reportedly sent to Zhuge Liang the gifts of a jade ring (jue 玦), a brocatelle (zhicheng 織成) safeguard and some storax incense (suhe xiang 蘇合香). A Shu officer leaked the information to Shen Yi 申儀, a Wei magistrate. According to the Shu officer, "Zhuge Liang said, 'The jade ring (jue) means Meng had made up his mind (jue); zhicheng means a plan has been formed (cheng); storax incense (suhe xiang) means things have fallen into place (he)’”玉玦者巳決, 織成者言謀巳成, 蘇合香者言事巳合. The story may be apocryphal, but it shows that giving symbolic interpretation of gifts was a distinctly acceptable possibility. Taiping yulan 359.1780. 


\section{Bibliography}

Cao Cao 曹操. Cao Cao ji yizhu 曹操集譯注. Annotated by Anhui Bo xian Cao Cao ji yizhu xiaozu 安徽毫縣曹操集譯注小組. Beijing: Zhonghua shuju, 1979.

---. Cao Cao ji zhu 曹操集注. Annotated by Xia Chuancai 夏傳才. He’nan: Zhongzhou guji shubanshe, 1986.

Chunqiu Zuo zhuan zhengyi 春秋左傳正義. See Shisanjing zhushu.

Curta, Florin. "Merovingian and Carolingian Gift Giving,” Speculum, 81.3 (2006): 671-99.

Derrida, Jacques. Given Time. 1. Counterfeit Money. Translated by Peggy Camuf. Chicago: University of Chicago Press, 1992.

Er ya zhushu 爾雅注疏. See Shisanjing zhushu.

Gu wen yuan 古文苑. Annotated by Zhang Qiao 章樵 (d. 1235). Sibu congkan edition.

Gurevich, A. J. Categories of Medieval Culture, translated by G. L. Campbell. London:

Routledge, 1985.

Han Wei liuchao biji xiaoshuo daguan 漢魏六朝筆記小說大觀. Shanghai: Shanghai guji chubanshe, 1999.

Han shu 漢書. Compiled by Ban Gu 班固. Beijing: Zhonghua shuju, 1962.

Harwood, Britton J. "Gawain and the Gift,” in PMLA, 106.3 (May 1991): 483-99.

Hawkes, David, trans. The Songs of the South: An Ancient Chinese Anthology of Poems by Qu Yuan and Other Poets. New York: Penguin Books, 1985.

Hou Han shu 後漢書. Compiled by Fan Ye 范曄 (398-446). Beijing: Zhonghua shuju, 1965.

Huainanzi 淮南子. Compiled by Liu An 劉安 (179-122 B.C.E.). Taibei: Zhonghua shuju, 1981. 
Jiang Yaling 江雅玲, Wen xuan zengda shi liubianshi 文選贈答詩流變史. Taibei: Wenjin chubanshe, 1999.Jin shu 晉書. Compiled by Fang Xuanling 房玄齡 (579-648) et al. Beijing: Zhonghua shuju, 1974.

Knechtges, David R. "Gradually Entering the Realm of Delight: Food and Drink in Early Medieval China.” 117.2 (1997): 229-39.

Kongzi jiayu shuzheng 孔子家語疏證. Annotated by Chen Shike 陳士珂. Shanghai shudian, 1987.

Lidai shufa lunwe xuan 歷代書法論文選. Shanghai: Shanghai shuhua chubanshe, 1979.

Li ji zhushu 禮記注疏. See Shisanjing zhushu.

Liu Xiang 劉向. Shuo yuan shuzheng 說苑疏證. Annotated by Zhao Shanyi 趙善詒. Shanghai: Huadong shifan daxue chubanshe, 1985.

Liu Xie 劉劦思. Wenxin diaolong yizheng 文心雕龍義證. Annotated by Zhan Ying 詹鍈.

Shanghai: Shanghai guji chubanshe, 1989.

Lü Buwei 呂不韋. Lüshi chunqiu jiaoshi 呂氏春秋校釋. Annotated by Chen Qiyou 陳奇猷.

Shanghai: Xuelin chubanshe, 1984.

Mao shi zhengyi 毛詩正義. See Shisanjing zhushu.

Mauss, Marcel. The Gift: Forms and Functions of Exchange in Archaic Societies. Translated by Ian Cunnison. New York: W. W. Norton, 1967.

Miller, William Ian. "Gift, Sale, Payment, Raid: Case Studies in the Negotiations and Classification of Exchange in Medieval Iceland." Speculum 61.1 (1986): 18-50.

Nan shi 南史. Compiled by Li Yanshou 李延壽 (fl. $7^{\text {th }}$ century). Beijing: Zhonghua shuju, 1975. 
Owen, Stephen. Readings in Chinese Literary Thought. Cambridge, MA: Harvard University Press, 1992.

Quan Han wen 全漢文. In Quan shanggu Sandai Qin Han Sanguo Liuchao wen 全上古三代三 國六朝文. Compiled by Yan Kejun 嚴可均 (1762-1843). Beijing: Zhonghua shuju, 1958.

Quan hou Han wen 全後漢文. In Quan shanggu Sandai Qin Han Sanguo Liuchao wen 全上古 三代三國六朝文. Compiled by Yan Kejun. Beijing: Zhonghua shuju, 1958.

Quan Liang wen 全梁文. In Quan shanggu Sandai Qin Han Sanguo Liuchao wen 全上古三代三 國六朝文. Compiled by Yan Kejun. Beijing: Zhonghua shuju, 1958.

Quan Sanguo wen 全三國文. In Quan shanggu Sandai Qin Han Sanguo Liuchao wen 全上古三 代三國六朝文. Compiled by Yan Kejun. Beijing: Zhonghua shuju, 1958.

Richter, Antje. Letters and Epistolary Culture in Early Medieval China. Seattle: University of Washington Press, 2013.

Sanguo zhi 三國志. Compiled by Chen Shou 陳壽 (233-97). Beijing: Zhonghua shuju, . Schwartz, Barry. "The Social Psychology of the Gift," American Journal of Sociology 73.1 (July 1967): 1-11.

Shanhai jing jiaozhu 山海經校註. Annotated by Yuan Ke 袁珂. Shanghai: Shanghai guji chubanshe, 1980.

Shi ji 史記. Compiled by Sima Qian 司馬遷 (ca. 145-85 B.C.E.). Beijing: Zhonghua shuju, 1959. Shisanjing zhushu十三經注疏. Compiled by Ruan Yuan 阮元 (1764-1849). Taibei: Yiwen yinshuguan, 1955.

Simmel, Georg. On Individuality and Social Forms: Selected Writings. Translated by Donald Levine. Chicago: University of Chicago Press, 1971. 
Sui shu 隋書. Compiled by Wei Zheng 魏徵 (580-643) et al. Beijing: Zhonghua shuju, 1973.

Taiping yulan 太平御覽. Taibei: Shangwu yinshuguan, 1975 reprint.

Tian, Xiaofei. Beacon Fire and Shooting Star: The Literary Culture of the Liang (501-557).

Cambridge, MA: Harvard Asia Center, 2007.

Wang, Xiaojuan 王曉鵑. Gu wenyuan lungao 古文苑論稿. Beijing: Renmin chubanshe, 2010.

Wen xuan 文選. Compiled by Xiao Tong 蕭統 (501-31). Shanghai: Shanghai guji chubanshe, 1994.

Yin Yun 殷芸. Yin Yun xiaoshuo 殷芸小說. Compiled and annotated by Zhou Lengjia 周楞伽.

Shanghai: Shanghai guji chubanshe, 1984.

Yiwen leiju 藝文類聚. Compiled by Ouyang Xun 歐陽詢 (557-641) et al. Taipei: Wenguang chubanshe, 1974.

Xian Qin Han Wei Jin Nanbeichao shi 先秦漢魏晉南北朝詩, edited by Lu Qinli 逯欽立. Beijing: Zhonghua shuju, 1995.

Zhao Yiwu 趙以武. Changhe shi yanjiu 唱和詩研究. Lanzhou: Gansu wenhua chubanshe, 1997. Zhuangzi jishi 莊子集釋. Compiled by Guo Qingfan 郭慶藩 (1844-1896). Beijing: Zhonghua shuju, 1961. 


\section{Index terms}

Gift: gift-giving; gift exchange; return gift

Jian'an

Mauss, Marcel

Reciprocity

Derrida, Jacques

Zhuge Liang

Sima Yi

Sun Sheng

Weishi chunqiu

Pei Songzhi

Xie An

Wang Xianzhi

Cao Cao

Yang Biao

Lady Bian (Cao Cao's wife)

Lady Yuan (Yang Biao's wife)

Yang Xiu

Cao Pi: "Discourse on Literature" ("Lun wen"); “Grand" (“Shanzai xing”); Normative

Discourses (Dian lun)

Cao Zhi: "Fu on Orange" (Ju fu")

Beitang shuchao

Chuxue ji 
Zhang Huaiguan

Shu duan

Sima Biao

Xu Han shu

Zhong Yao

Wei lue

Yu Huan

Li Shan

Bian $\mathrm{He}$

He's Jade

Shi jing: "Juan E"; “Ju xia"

Ji Pingzi

Yang $\mathrm{Hu}$

Zhongliang Huai

Junzi ("noble man")

Fan Sui

King Zhao of Qin

Wang Yi

Zhengbu lun

Zhang Hong

Ying Yang

Jing Ke

Lin Xiangru 
Kunlun Mountain

Georg Simmel

Handan Chun

Aaron Gurevich

Qu Yuan (Qu Ping)

"Li sao"

Kong Rong

Cao Song

Sun Quan

Chu Yuan

Zhao Zi

Wu li

Hu Chong

Liu Bei

Liu Ye

Meng Da

Qi (qishi)

Zengda shi ("presentation-reply poetry")

Dao Gai

Ren Fang

Wang Yun

Xie Ju

Liu Xiaowei 
Liu Lingxian

Xu Fei

Xiao Gang (Emperor Jianwen of the Liang)

Lu Ji: "Fu on Melon" (“Gua fu”)

Shen Ying

Linhai yiwu zhi

Zhang Hua

Bowu zhi

Guo Pu

Yongwu fu ("poetic expositions on things")

Yongwu shi ("poetry on things")

Liu Xie

Wenxin diaolong

Emperor Wu of the Liang

Xiao Tong

Xiao Yi

Fu Qian

Tongsu wen

Liu Qian (see Liu Xiaoyi)

Liu Xiaoyi

Yang Fu

Yiwu zhi

Ji Han 
Nanfang caomu zhuang

Li Heng

Rang Prefecture

Zhang Heng: "Fu on the Southern Metropolis" ("Nan du fu")

Wu Zhi

Shiqian Palace

Ying Zhen: "Fu on Pomegranate" (“Anshiliu fu”)

Yu Jianwu

Li You: "Qi kuan"

Liu Zhen: "Fu on Melon” (“Gua fu”)

Liu Jun

Han Yanzhi

Ju lu

Liu Xiang

Yanzi

Duke Jing of Qi

"Ode to the Orange" ("Ju song")

"Nine Pieces" ("Jiu zhang”)

Lyrics of Chu (Chu ci): "Li sao"; "Ju song"; "Jiu zhang"

Hawkes, David

Chunqiu yundoushu

Yang Xiong, "Fu on the Shu Capital" ("Shu du fu")

Ying Shao 
Yi Yin shu

Jiang Yan: "Fu on Lamenting a Thousand Leagues" (“Ai qianli fu”)

Diao Cun

Emperor Huan of the Han

Zhan lue

Shen Yi

Fan Zhen

Fayun

Hongming ji 
List of recommended reading:

Ho, Richard M.W., trans. "Cao Zhi: Letter to Yang Dezu.” Renditions 41\&42 (Spring and Autumn 1994): 12-14.

Richter, Antje. Letters and Epistolary Culture in Early Medieval China. Seattle: University of Washington Press, 2013.

---. “Beyond Calligraphy: Reading Wang Xizhi’s Letters.” In T'oung Pao, Second Series, Vol. 96, Fasc. 4/5 (2010): 370-407.

Su, Jui-lung. "Bao Zhao: Letter to My Younger Sister upon Ascending the Bank of Thunder Lake.” Renditions 41\&42 (Spring and Autumn 1994): 18-24.

Wang Youfen, trans., "Lu Ji's letter on recovery from an illness," in Chinese Calligraphy, ed.

Ouyang Zhongshi and Wen C. Fong. New Haven: Yale University Press, 2008: 148-149.

Watson, Burton. “Cao Pi: Two Letters to Wu Zhi, Magistrate of Zhaoge.” Renditions $41 \& 42$ (Spring and Autumn 1994): 7-11.

Wu, Sujane. Clarity, Brevity, and Naturalness: Lu Yun and His Works. Ph.D. diss., University of Wisconsin, Madison, 2001: 208-238. 